Argonne

\title{
Final Corrective Action Study for the Former CCC/USDA Facility in, Ramona, Kansas
}

\author{
Environmental Science Division
}


About Argonne National Laboratory

Argonne is a U.S. Department of Energy laboratory managed by UChicago Argonne, LLC under contract DE-AC02-06CH11357. The Laboratory's main facility is outside Chicago, at 9700 South Cass Avenue, Argonne, Illinois 60439. For information about Argonne and its pioneering science and technology programs, see www.anl.gov.

\section{Availability of This Report}

This report is available, at no cost, at http://www.osti.gov/bridge. It is also available on paper to the U.S. Department of Energy and its contractors, for a processing fee, from:

U.S. Department of Energy

Office of Scientific and Technical Information

P.O. Box 62

Oak Ridge, TN 37831-0062

phone (865) 576-8401

fax (865) 576-5728

reports@adonis.osti.gov

\section{Disclaimer}

This report was prepared as an account of work sponsored by an agency of the United States Government. Reference herein to any specific commercial product, process, or service by trade name, trademark, manufacturer, or otherwise, does not necessarily constitute or imply its endorsement, recommendation, or favoring by the United States Government or any agency thereof. The views and opinions of document authors expressed herein do not necessarily state or reflect those of the United States Government or any agency thereof, Argonne National Laboratory, or UChicago Argonne, LLC. 


\section{Final Corrective Action Study for the Former CCC/USDA Facility in, Ramona, Kansas}

by

Applied Geosciences and Environmental Management Section Environmental Science Division, Argonne National Laboratory

March 2011 


\section{Contents}

Notation.

1 Introduction

2 Site Background

2.1 Site Description.

2.2 Environmental Setting

2.3 Nature and Extent of Soil and Groundwater Contamination.

2.3.1 Previous Investigations at Ramona.

2.3.2 Argonne 2006 Investigation at the Former CCC/USDA Grain Storage Facility.....

2.3.3 KDHE 2006 Investigation in the Wider Ramona Area

2.3.4 Argonne 2009 Groundwater Sampling at the Former CCC/USDA Facility

2.4 Geologic and Hydrogeologic Conditions at the Former CCC/USDA Facility.........

2.5 Evaluation of Current and Future Human and Environmental Exposure

Targets and Pathways

2.5.1 Water Sources for Ramona....

2.5.2 Water-Supply-Related Pathway

2.5.3 Vapor Intrusion Pathway

3.1 Site-Specific Goals.

3.2 Regulatory Considerations

3.2.1 Applicable or Relevant and Appropriate Requirements and Guidance to be Considered

3.2.2 Voluntary Environmental Use Controls.....

3.2.3 Waivers and Variances

4 Description of Alternatives.

4.1 Alternative 1: No Action.

4-1

4.2 Alternative 2: Monitoring....

4.3 Alternative 3: Environmental Use Controls

4.4 Alternative 4: In Situ Chemical Reduction

5.1 Alternative 1: No Action. 


\section{Contents (Cont.)}

5.1.2 Compliance with ARARs .............................................................. 5-3

5.1.3 Long-Term Effectiveness and Permanence ……...................................... 5-3

5.1.4 Reduction of Toxicity, Mobility, or Volume …………………………...... 5-4

5.1.5 Short-Term Effectiveness ...................................................................... 5-4

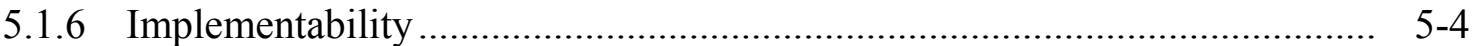

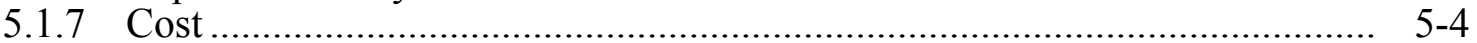

5.2 Alternative 2: Monitoring ..................................................................................... 5

5.2.1 Overall Protection of Human Health and the Environment .......................... 5-4

5.2.2 Compliance with ARARs ..................................................................... 5-5

5.2.3 Long-Term Effectiveness and Permanence ................................................. 5-5

5.2.4 Reduction of Toxicity, Mobility, or Volume …………................................ 5-5

5.2.5 Short-Term Effectiveness .............................................................. 5-6

5.2.6 Implementability ........................................................................ $5-6$

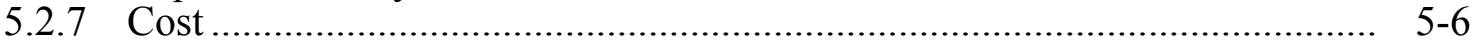

5.3 Alternative 3: Environmental Use Controls....................................................... 5-6

5.3.1 Overall Protection of Human Health and the Environment ........................... 5-6

5.3.2 Compliance with ARARs ................................................................. 5-7

5.3.3 Long-Term Effectiveness and Permanence ………..................................... 5-7

5.3.4 Reduction of Toxicity, Mobility, or Volume ………................................... 5-7

5.3.5 Short-Term Effectiveness ................................................................. $5-7$

5.3.6 Implementability ...................................................................... $5-8$

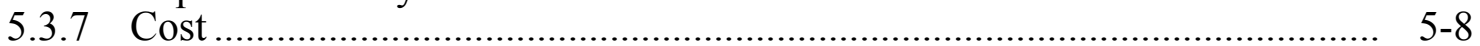

5.4 Alternative 4: In Situ Chemical Reduction .............................................................. $5-8$

5.4.1 Overall Protection of Human Health and the Environment ........................... 5-8

5.4.2 Compliance with ARARs .......................................................................... 5-9

5.4.3 Long-Term Effectiveness and Permanence ……....................................... 5-9

5.4.4 Reduction of Toxicity, Mobility, or Volume …………………………........ 5-10

5.4.5 Short-Term Effectiveness ....................................................................... 5-10

5.4.6 Implementability .................................................................................. 5-10

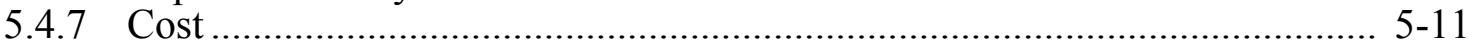

6 Comparative Analysis of Alternatives ........................................................................... 6-1

6.1 Threshold Criteria ....................................................................................... 6 6-1

6.1.1 Overall Protection of Human Health and the Environment.......................... 6-1

6.1.2 Compliance with ARARs ………………………....................................... 6-1

6.2 Primary Balancing Criteria ……………………............................................... 6-2

6.2.1 Long-Term Effectiveness and Permanence ............................................. 6-2

6.2.2 Reduction of Toxicity, Mobility, or Volume …………………..................... 6-2

6.2.3 Short-Term Effectiveness ................................................................... 6-2

6.2.4 Implementability ................................................................ 6 6-3

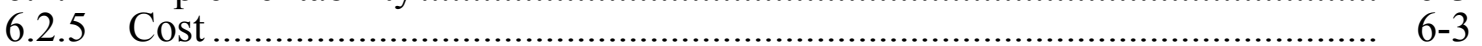

6.3 Modifying Criteria (Stakeholder and State Acceptance) ........................................... 6-4

6.4 Summary and Recommended Corrective Action .................................................. 6-4

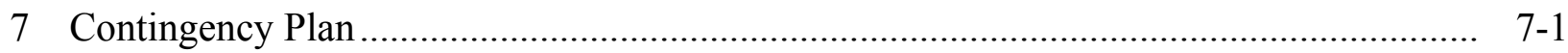

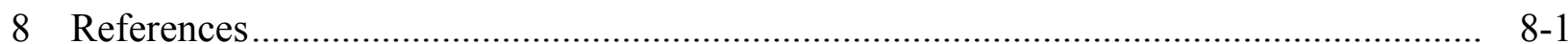




\section{Contents (Cont.)}

Appendix A: Potential Federal and State Applicable or Relevant and Appropriate Requirements and State Guidance Documents "To Be Considered"

Appendix B: Basis for Cost Estimation for Ramona CAS

\section{Figures}

2.1 Location of Ramona, Kansas

2.2 Locations of former grain storage facilities at Ramona

2.3 Boundaries of the former CCC/USDA property and the Brady property

2.4 Locations of permanent piezometers installed by the CCC/USDA in 2006 .

2.5 Maximum concentrations of carbon tetrachloride detected in groundwater samples collected on and upgradient from the former CCC/USDA property in 2006

2.6 Maximum concentrations of chloroform detected in groundwater samples collected on and upgradient from the former CCC/USDA property in 2006

2.7 Maximum concentrations of carbon tetrachloride detected in soil samples collected on the former CCC/USDA property in 2006.

2.8 Interpreted lateral distribution of carbon tetrachloride in groundwater in the wider area at Ramona, based on results of the KDHE investigation in 2006.

2.9 Maximum carbon tetrachloride concentrations detected in the CCC/USDA groundwater sampling in April 2009

2.10 Potentiometric surface at Ramona, as interpreted from water level measurements made on July 20, 2006, and September 1, 2006

2.11 Potentiometric surface at Ramona, as interpreted from water level measurements made on October 15, 2006, and November 1, 2006

2.12 Water level contours constructed with data measured manually on August 27, 2009 


\section{Figures (Cont.)}

2.13 Groundwater surface elevations in piezometers located at the former CCC/USDA

facility in January 2008-September 2009

4.1 Proposed well locations for Alternative 4

\section{Tables}

2.1 Concentrations of volatile organic compounds in groundwater samples collected at the CCC/USDA's permanent monitoring points at Ramona, July 2006-April 2009

4.1 Characteristics and costs of Alternatives 1-4 for $5 \mathrm{yr}, 9 \mathrm{yr}$, or $10 \mathrm{yr}$ of implementation.

4.2 Monitoring, reporting, and review tasks for Alternative 2

4.3 Monitoring, reporting, and review tasks for Alternative 3

4.4 Treatment, monitoring, reporting, and review tasks for Alternative 4

6.1 Comparative analysis of aquifer restoration alternatives

A.1 Potential federal applicable or relevant and appropriate requirements for former $\mathrm{CCC} / \mathrm{USDA}$ facilities in Kansas

A.2 Potential state applicable or relevant and appropriate requirements for former $\mathrm{CCC} / \mathrm{USDA}$ facilities in Kansas

A.3 State guidance documents "to be considered" for former CCC/USDA facilities in Kansas.... 


\section{Notation}

$\begin{array}{ll}\text { ARAR } & \text { applicable or relevant and appropriate requirement } \\ \text { BGL } & \text { below ground level } \\ \text { CAS } & \text { Corrective Action Study } \\ \text { CCC } & \text { Commodity Credit Corporation } \\ \text { CERCLA } & \text { Comprehensive Environmental Response, Compensation, and Liability Act } \\ \text { EPA } & \text { U.S. Environmental Protection Agency } \\ \text { EUC } & \text { Environmental Use Control } \\ \text { ft } & \text { foot (feet) } \\ \text { hr } & \text { hour(s) } \\ \text { ISCR } & \text { in situ chemical reduction } \\ \text { KDHE } & \text { Kansas Department of Health and Environment } \\ \text { Kh } & \text { horizontal hydraulic conductivity } \\ \text { LTC } & \text { long-term care } \\ \mu \mathrm{g} / \mathrm{kg} & \text { microgram(s) per kilogram } \\ \mu \mathrm{g} / \mathrm{L} & \text { microgram(s) per liter } \\ \text { mg/L } & \text { milligram(s) per liter } \\ \text { mi } & \text { mile(s) } \\ \text { MCL } & \text { maximum contaminant level } \\ \text { NPV } & \text { net present value } \\ \text { NCP } & \text { National Oil and Hazardous Substances Pollution Contingency Plan } \\ \text { RBSL } & \text { risk-based screening level } \\ \text { RCRA } & \text { Resource Conservation and Recovery Act } \\ \text { RWD } & \text { Rural Water District } \\ \text { TBC } & \text { to be considered } \\ \text { USDA } & \text { U.S. Department of Agriculture } \\ \text { VOC } & \text { volatile organic compound } \\ \text { yr } & \text { year(s) } \\ & \end{array}$




\section{Final Corrective Action Study for the Former CCC/USDA Facility in Ramona, Kansas}

\section{Executive Summary}

Past operations at a grain storage facility formerly leased and operated by the Commodity Credit Corporation of the U.S. Department of Agriculture (CCC/USDA) in Ramona, Kansas, resulted in low concentrations of carbon tetrachloride in groundwater that slightly exceed the regulatory standard in only one location. As requested by the Kansas Department of Health and Environment, the CCC/USDA has prepared a Corrective Action Study (CAS) for the facility. The CAS examines corrective actions to address groundwater impacted by the former CCC/USDA facility but not releases caused by other potential groundwater contamination sources in Ramona. Four remedial alternatives were considered in the CAS. The recommended remedial alternative in the CAS consists of Environmental Use Control to prevent the inadvertent use of groundwater as a water supply source, coupled with groundwater monitoring to verify the continued natural improvement in groundwater quality. 


\section{Introduction}

The Commodity Credit Corporation of the U.S. Department of Agriculture (CCC/USDA) has directed Argonne National Laboratory to prepare a Corrective Action Study (CAS), consistent with guidance from the Kansas Department of Health and Environment (KDHE 2001a), for the CCC/USDA grain storage facility formerly located in Ramona, Kansas. This effort is pursuant to a KDHE (2007a) request.

Although carbon tetrachloride levels at the Ramona site are low, they remain above the Kansas Tier 2 risk-based screening level (RBSL) and the U.S. Environmental Protection Agency (EPA) maximum contaminant level (MCL) of $5 \mu \mathrm{g} / \mathrm{L}$ (Kansas 2003, 2004). In its request for the CAS, the KDHE (2007a) stated that, because of these levels, risk is associated with potential future exposure to contaminated groundwater. The KDHE therefore determined that additional measures are warranted to limit future use of the property and/or exposure to contaminated media as part of site closure. The KDHE further requested comparison of at least two corrective action alternatives to the "no-action" alternative, as the basis for the Draft Corrective Action Decision for the site.

The history and nature of the contamination and previous investigations are summarized in Section 2. Also included in Section 2 is an evaluation of human and environmental targets and potential exposure pathways. Section 3 describes the corrective action goals and applicable or relevant and appropriate requirements (ARARs). Section 4 describes four alternatives, Section 5 analyzes the alternatives in detail, and Section 6 compares the alternatives. Section 6 also includes a summary and a recommended corrective action. 


\section{Site Background}

\subsection{Site Description}

Ramona, Kansas, is a small rural town with 94 residents (2000 Census). Located in the north central portion of Marion County, Ramona is 104 mi southwest of Topeka, Kansas, in the SE 1/4 of Section 2, Township 17 South, Range 3 East (Figure 2.1). Grain storage has occurred over the years at multiple locations in Ramona, including the former CCC/USDA facility, the facility operated by the Tampa Cooperative Association (the Co-op), and several privately owned locations along the east and south edges of the town (Figure 2.2). The Co-op operates north and west of the Union Pacific Railroad right-of-way.

From 1950 to 1966 , the CCC/USDA operated a grain storage facility on one acre of leased land in the southeast part of Ramona. No structures remain on the property. The land is currently used for agriculture, specifically brome production. The property (506 East First Street; Figure 2.3) is currently privately owned and is located within the Ramona municipal boundaries. For tax purposes, the property is zoned RU, residential urban.

The principal water source for Ramona residents is the Marion County Rural Water District (RWD) \#1. This water supply source became available in September 1995 under an emergency grant from the USDA Farmers Home Administration. The water is delivered to Ramona via a connection to the RWD \#1 supply in Tampa, Kansas, about 5 mi southwest of Ramona. Before the connection to RWD \#1 was established, all Ramona residents used private water wells for their drinking water supply. Private well depths range from $40 \mathrm{ft}$ to $100 \mathrm{ft} \mathrm{BGL}$ (below ground level). The depth to groundwater near the former CCC/USDA facility is generally about 45-50 ft BGL.

\subsection{Environmental Setting}

Ramona lies in the Flint Hills physiographic province, which is noted for its steep eastfacing escarpments. Surface soils generally consisting of silty clay loam are underlain by shale of the Wellington Formation. The thickness of this shale ranges from $30 \mathrm{ft}$ to $55 \mathrm{ft}$. Below the Wellington is interbedded limestone and shale associated with the Nolans Formation. The Nolans Formation, in turn, is underlain by the Odell Formation. In the Ramona area the Nolans 
formation is $21-26 \mathrm{ft}$ thick, and the Odell shale is about $20-30 \mathrm{ft}$ thick. Water-bearing zones in these consolidated formations supply adequate quantities of groundwater for domestic purposes. In the Ramona area, multiple aquifers are present. Groundwater flow has been variously described as being either to the northwest or to the southeast. Servi-Tech (2008) noted that the apparent discrepancy in the inferred groundwater flow direction might be the result of combining measurements from multiple aquifers. Groundwater flow is to the north and northeast beneath the portion of the former CCC/USDA facility impacted by carbon tetrachloride contamination. In contrast, groundwater flow is to the north and northwest in the vicinity of the Co-op property and across much of the area lying west and northwest of the former CCC/USDA facility.

\subsection{Nature and Extent of Soil and Groundwater Contamination}

\subsubsection{Previous Investigations at Ramona}

Earlier investigations at Ramona have been described in detail (Argonne 2005). In these investigations, more than 300 groundwater samples were collected from nearly 100 wells. Nitrates and numerous volatile organic compounds (VOCs) were detected in many wells. The most persistent compounds are those related to petroleum products, as well as carbon tetrachloride and nitrates. The existing monitoring wells at Ramona are typically 38-53 ft deep.

\subsubsection{Argonne 2006 Investigation at the Former CCC/USDA Grain Storage Facility}

Argonne's 2006 investigation of contaminant sources at Ramona was implemented on behalf of the CCC/USDA and was conducted at the request of the KDHE (2005a). The investigation involved the following activities:

- Cone penetrometer electronic sensor logging

- Soil sampling and analyses

- Piezometer installation

- Groundwater sampling and analyses 
- Measurement of groundwater levels and installation of data loggers

The results of the 2006 investigation were reported previously (Argonne 2007). The locations of the five permanent piezometers installed in 2006 are shown in Figure 2.4. The results for carbon tetrachloride and chloroform in groundwater are summarized in Figures 2.5 and 2.6, respectively. Carbon tetrachloride was found in groundwater at concentrations above the RBSL and MCL values in only two samples, both collected in the southeast corner of the former facility $(23 \mu \mathrm{g} / \mathrm{L}$ at TI10 and $6.3 \mu \mathrm{g} / \mathrm{L}$ at MW07; Figure 2.5). The area of carbon tetrachloride contamination shown in Figure 2.5 is interpreted to lie entirely on the former CCC/USDA property and is restricted to the upper part (45-55 ft BGL) of the saturated zone. No carbon tetrachloride concentrations above the RBSL and MCL values were identified from $55 \mathrm{ft}$ BGL to cone penetrometer refusal at $62 \mathrm{ft}$ to $87 \mathrm{ft}$ BGL.

In soil, carbon tetrachloride was found at quantifiable concentrations in three samples collected just above the saturated zone at one location, also in the southeast corner of the former facility. The maximum concentration was $14 \mu \mathrm{g} / \mathrm{kg}$ at $39.5 \mathrm{ft}$ BGL (Figure 2.7). The RBSL for the soil-to-groundwater protection pathway is $200 \mu \mathrm{g} / \mathrm{kg}$. The low carbon tetrachloride values detected demonstrate that the soil at the Ramona site is not an ongoing significant source of contamination.

\subsubsection{KDHE 2006 Investigation in the Wider Ramona Area}

An independent KDHE investigation in 2006 generated results similar to those of the Argonne 2006 investigation for the former CCC/USDA facility, along with additional data over a wider area in Ramona (Figure 2.8). The KDHE (2006) concluded that the contamination detected on the former CCC/USDA property appeared to be separate from the source areas identified on the Co-op property. The KDHE further concluded that a near-surface source area had been identified on the Co-op property and stated, "It appears the principal source of carbon tetrachloride contamination in Ramona results from historical operations associated with the Co-op property" (KDHE 2006, pages 9-10). Carbon tetrachloride concentrations in groundwater ranged from not detected to $130 \mu \mathrm{g} / \mathrm{L}$ north and west of the railroad tracks near the Co-op. The carbon tetrachloride distribution in groundwater and water level contours, as interpreted by the KDHE, are in Figure 2.8. 


\subsubsection{Argonne 2009 Groundwater Sampling at the Former CCC/USDA Facility}

In April 2009, Argonne sampled the five piezometers shown in Figure 2.4 on behalf of the CCC/USDA. Table 2.1 summarizes the analytical results and, for comparison, includes the results for the preceding Argonne sampling in July 2006. Figure 2.9 illustrates the distribution of carbon tetrachloride at the former facility in April 2009.

In April 2009, each well was sampled twice. Purging of three well volumes prior to sampling is rarely possible at the Ramona site, because the wells in the monitoring well network recover so slowly after purging. On the first day, a sample of water available in the well casing was collected. Sampling on the second day occurred after purging to the extent possible. Carbon tetrachloride was detected at all of the locations sampled, except for MW04. Carbon tetrachloride and chloroform results in July 2006 and April 2009 were similar, except at MW07 (Table 2.1).

\subsection{Geologic and Hydrogeologic Conditions at the Former CCC/USDA Facility}

The site lithology, as identified through the collection of core samples from three boreholes during the 2006 investigation (Argonne 2007), consisted predominantly of silty clay to clayey silt with minor zones of silty clay with sand or gravel. Also observed at some depths were inclusions of calcite crystals that often showed vuggular porosity. No significant zones of sand or gravel were observed at any location on the former CCC/USDA property.

The data collected indicate the presence of only one aquifer underlying the former facility, at approximately 40-87 ft BGL. Core samples collected to a depth of $77 \mathrm{ft}$ BGL at three locations on the property showed no evidence of intermediate low-permeability intervals that might separate multiple aquifer zones hydraulically.

The piezometers installed on the former CCC/USDA facility (Figure 2.4) were screened at 45-55 $\mathrm{ft}$ BGL, in the only zone that exhibited carbon tetrachloride concentrations above the RBSL and MCL values of $5 \mu \mathrm{g} / \mathrm{L}$. This zone produced minimal quantities of water in all piezometers. Groundwater depths varied across the site, ranging between approximately $46.5 \mathrm{ft}$ and $52.5 \mathrm{ft} \mathrm{BGL.}$ 
Figures 2.10 and 2.11 show potentiometric surface maps, with interpreted flow directions, in the immediate vicinity of the former CCC/USDA property, for data collected on July 20, September 1, October 15, and November 1, 2006. These maps indicate predominant directions of groundwater flow to the north and northeast across the portion of the former $\mathrm{CCC} / \mathrm{USDA}$ facility in which groundwater contamination has been identified.

Groundwater level data measured continuously over a period of several years in wells MW04-MW08 at the former CCC/USDA property (east of the railroad tracks) have also indicated that groundwater flow is predominantly toward the north and northeast beneath the portion of the facility impacted by carbon tetrachloride contamination. These results are consistent with early observations during Argonne's 2006 investigation (Figures 2.10 and 2.11).

In the wider area, however, water level contours constructed by the KDHE (2006; Figure 2.8 in the present report) and contours constructed with data measured manually by Argonne on August 27, 2009 (Figure 2.12), illustrate that groundwater flow is toward the north and northwest in the vicinity of the Co-op property and across much of the area to the west and northwest of the former CCC/USDA facility.

During the 2006 investigation and subsequently, groundwater levels in piezometers were recorded manually (Argonne 2007). On July 20, 2006, Argonne placed data loggers in new piezometers MW04-MW08 and in previously existing wells SB02 and SB03. The data loggers have been recording water levels at 4-hr intervals until the present. Figure 2.13 depicts water level elevations measured automatically in piezometers MW04-MW08 (at the former facility) and SB03 (northwest of the former facility and the Co-op) from January 2008 to September 2009 (during which interval one of the data loggers failed briefly).

For assumed textbook values for (1) horizontal hydraulic conductivity $\left(K_{h}\right)$ of silty clay to clayey silt and (2) an assumed average porosity of $40 \%$ for the aquifer matrix, estimated groundwater flow rates at the former CCC/USDA facility would be expected to fall in the approximate range of 0.002-0.3 ft/day (Anderson and Woessner 1992). 


\subsection{Evaluation of Current and Future Human and Environmental Exposure Targets and Pathways}

At present, no environmental targets or exposure pathways appear to be associated with the former CCC/USDA facility. Both potential current and future human exposure pathways are related to groundwater. One pathway involves the use of contaminated groundwater for domestic or municipal water supply systems, while the other involves vapor intrusion.

\subsubsection{Water Sources for Ramona}

The principal water source for Ramona residents is the Marion County RWD \#1. By late 2005, most of Ramona's residences and businesses had switched from private wells to the RWD \#1 supply. In November 2004, Argonne conducted a preliminary survey to identify Ramona residences that might not be connected to RWD \#1. Records of the KDHE and RWD \#1 were reviewed, along with property ownership information from the Marion County appraiser's office. Subsequently, cross-indexing of the RWD \#1 customer list against the county property ownership records identified 19 properties for which water supply status was uncertain.

In September-October 2005, KDHE personnel conducted a telephone survey and a site visit to verify the status of the 19 properties. Of the 19 properties, 7 properties were verified to have a connection to RWD \#1, 3 addresses had no inhabitants and unknown water supplies, and 3 addresses were vacant lots with no water supplied. The KDHE attempted to sample the remaining 6 private wells in use for domestic consumption. Access to 1 well was denied; it has historically had high nitrate levels (KDHE 2005b). The KDHE sampled the remaining 5 wells in October 2005. Concentrations of carbon tetrachloride were below the RBSL and MCL values of $5 \mu \mathrm{g} / \mathrm{L}$ in all 5 wells.

The 6 private wells potentially remaining in use for domestic consumption are located north and west of the railroad tracks, the Co-op, and the former CCC/USDA facility. Although these wells could be affected by Co-op activities, they are not likely to be impacted by the identified contamination at the former CCC/USDA facility. Groundwater flow in the contaminated portion of the former facility is to the northeast, parallel to the railroad tracks and away from the 6 identified private wells. 
According to the mayor, the city has no restrictions or requirements prohibiting the installation and use of a water supply well within the incorporated area of Ramona; however, the mayor was not aware of the installation of any water supply well (Wick 2010).

The Marion County Sanitation Code (Marion County 1994) specifies that no person can drill, develop, or construct a well in an unincorporated area of the county until a permit is obtained and that no permit can be issued to the owner of a property that is served or that can be served at reasonable cost by a public water supply. The CCC/USDA requested information from Marion County regarding wells potentially drilled within $2 \mathrm{mi}$ of the city of Ramona. Staff from the Marion County Department of Planning and Zoning and Environmental Health determined that no new water supply well permits have been issued since mid 2005 (Richards 2009). However, Argonne's search of state records indicated that two wells have been installed: a domestic well $1.25 \mathrm{mi}$ southeast of the former CCC/USDA facility (owner Ronnie Hanschu, SE SE SE of S12 T17S R3E) and a livestock well approximately $0.75 \mathrm{mi}$ east of the former facility (owner Kent Brunner, NE SW SE of S1 T17S R3E).

\subsubsection{Water-Supply-Related Pathway}

The levels of carbon tetrachloride contamination detected in groundwater on the former $\mathrm{CCC} / \mathrm{USDA}$ property are low and are limited vertically and laterally. In the most recent sampling event, the highest carbon tetrachloride concentration detected was $12 \mu \mathrm{g} / \mathrm{L}$ in well MW07 (Table 2.1 and Figure 2.9). These low concentrations do not present a current threat and are not expected to pose a long-term threat. The only resident who could be a potential receptor is the present homeowner on the former CCC/USDA facility property, and that homeowner is served by RWD \#1.

Analytical data collected in 2006 at downgradient and cross-gradient locations TI07, TI08, TI09, TI15, TI16, and TI17 (Figure 2.5) delineated the extent of the impacted groundwater. The highest carbon tetrachloride concentration detected at these locations was $2.5 \mu \mathrm{g} / \mathrm{L}$ (at TI09). Carbon tetrachloride and chloroform levels detected in groundwater samples from all of these locations were below the respective MCL and RBSL values of $5 \mu \mathrm{g} / \mathrm{L}$ and $80 \mu \mathrm{g} / \mathrm{L}$. These results indicate that the full vertical and lateral extent of the groundwater contamination has been identified. 
No complete pathways are known to exist from contaminated groundwater to human or environmental receptors, given the availability of the RWD \#1 connection, the results of the well surveys, the lateral limits and location of the contaminated groundwater, and the absence of a known water supply well for either domestic or livestock purposes that intercepts the contamination on the former CCC/USDA facility property. Furthermore, where the carbon tetrachloride concentrations exceed the RBSL and MCL values, the hydraulic gradient is to the northeast, toward unincorporated Marion County land, where the Sanitation Code (Marion County 1994) is applicable.

\subsubsection{Vapor Intrusion Pathway}

Kansas vapor intrusion guidance (KDHE 2007b) defines "buildings of concern" for chlorinated VOCs as those within $100 \mathrm{ft}$ laterally or $40 \mathrm{ft}$ vertically of the contamination. The depths to groundwater at the former CCC/USDA facility are greater than $40 \mathrm{ft}$, and no buildings are within $100 \mathrm{ft}$ laterally of the extent of the impacted groundwater, as illustrated in Figure 2.5. Consequently, under the KDHE (2007b) guidance, vapor intrusion is not considered a complete exposure pathway. 
TABLE 2.1 Concentrations of volatile organic compounds in groundwater samples collected at the CCC/USDA's permanent monitoring points at Ramona, July 2006-April 2009. ${ }^{a}$

\begin{tabular}{|c|c|c|c|c|c|c|c|}
\hline \multirow[b]{2}{*}{ Location } & \multirow[b]{2}{*}{ Sample } & \multirow[b]{2}{*}{$\begin{array}{l}\text { Sample } \\
\text { Date }\end{array}$} & \multicolumn{2}{|c|}{ Depth (ft BGL) } & \multicolumn{3}{|c|}{ Concentration $(\mu \mathrm{g} / \mathrm{L})$} \\
\hline & & & $\begin{array}{l}\text { Screen } \\
\text { Interval }\end{array}$ & Groundwater & $\begin{array}{c}\text { Carbon } \\
\text { Tetrachloride }\end{array}$ & Chloroform & $\begin{array}{l}\text { Methylene } \\
\text { Chloride }\end{array}$ \\
\hline MW04 & RATI16-W-21449 & $7 / 13 / 06$ & $45-55$ & 51 & $N D^{b}$ & ND & ND \\
\hline MW04 & RAMW4-W-21466 & $4 / 27 / 09$ & $45-55$ & 46 & ND & ND & ND \\
\hline MW04 & RAMW4-W-21472 & $4 / 28 / 09$ & $45-55$ & & ND & ND & ND \\
\hline MW05 & RATI17-W-21450 & $7 / 13 / 06$ & $45-55$ & 47 & $0.9 \mathrm{~J}^{\mathrm{c}}$ & $0.3 \mathrm{~J}$ & ND \\
\hline MW05 & RAMW5-W-21467 & $4 / 27 / 09$ & $45-55$ & 47 & 2.1 & ND & ND \\
\hline MW05 & RAMW5-W-21473 & $4 / 28 / 09$ & $45-55$ & & 1.7 & $0.4 \mathrm{~J}$ & ND \\
\hline MW06 & RATI18-W-21452 & $7 / 13 / 06$ & $45-55$ & 50 & 1.8 & 1.1 & ND \\
\hline MW06 & RAMW6-W-21468 & $4 / 27 / 09$ & $45-55$ & 49 & 1.5 & ND & ND \\
\hline MW06 & RAMW6-W-21474 & 4/28/09 & $45-55$ & & 2.4 & $0.3 \mathrm{~J}$ & ND \\
\hline MW07 & RATI19-W-21453 & $7 / 13 / 06$ & $45-55$ & 50 & 6.3 & 1.6 & ND \\
\hline MW07 & RAMW7-W-21469 & $4 / 27 / 09$ & $45-55$ & 49 & 12 & 1.7 & ND \\
\hline MW07 & RAMW7-W-21475 & 4/28/09 & $45-55$ & & 10 & 1.7 & ND \\
\hline MW08 & RATI20-W-21451 & $7 / 13 / 06$ & $45-55$ & 47 & $0.7 \mathrm{~J}$ & ND & ND \\
\hline MW08 & RAMW8-W-21470 & 4/27/09 & $45-55$ & 47 & ND & ND & ND \\
\hline MW08 & RAMW8-W-21476 & 4/28/09 & $45-55$ & & $0.8 \mathrm{~J}$ & ND & ND \\
\hline
\end{tabular}

a Because purging of three well volumes is rarely possible at Ramona, the following sampling strategy was used in April 2009: (1) on the first day, a sample of the water available in each well casing was obtained; (2) on the second day, samples were collected after well purging to the extent possible.

b ND, not detected at instrument detection limit of $0.1 \mu \mathrm{g} / \mathrm{L}$.

c Qualifier J indicates an estimated concentration below the purge-and-trap method quantitation limit of $1.0 \mu \mathrm{g} / \mathrm{L}$. 


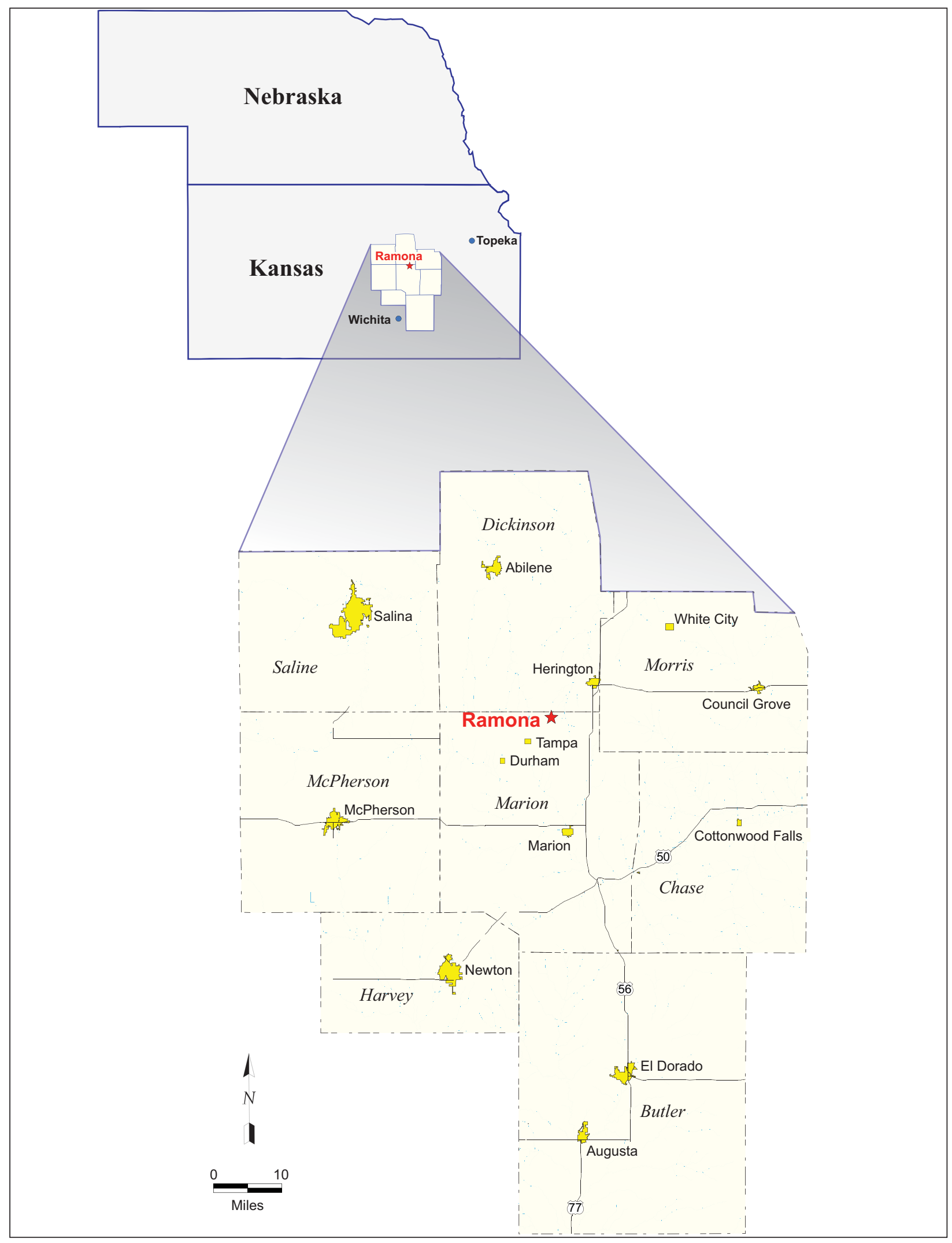

FIGURE 2.1 Location of Ramona, Kansas. 


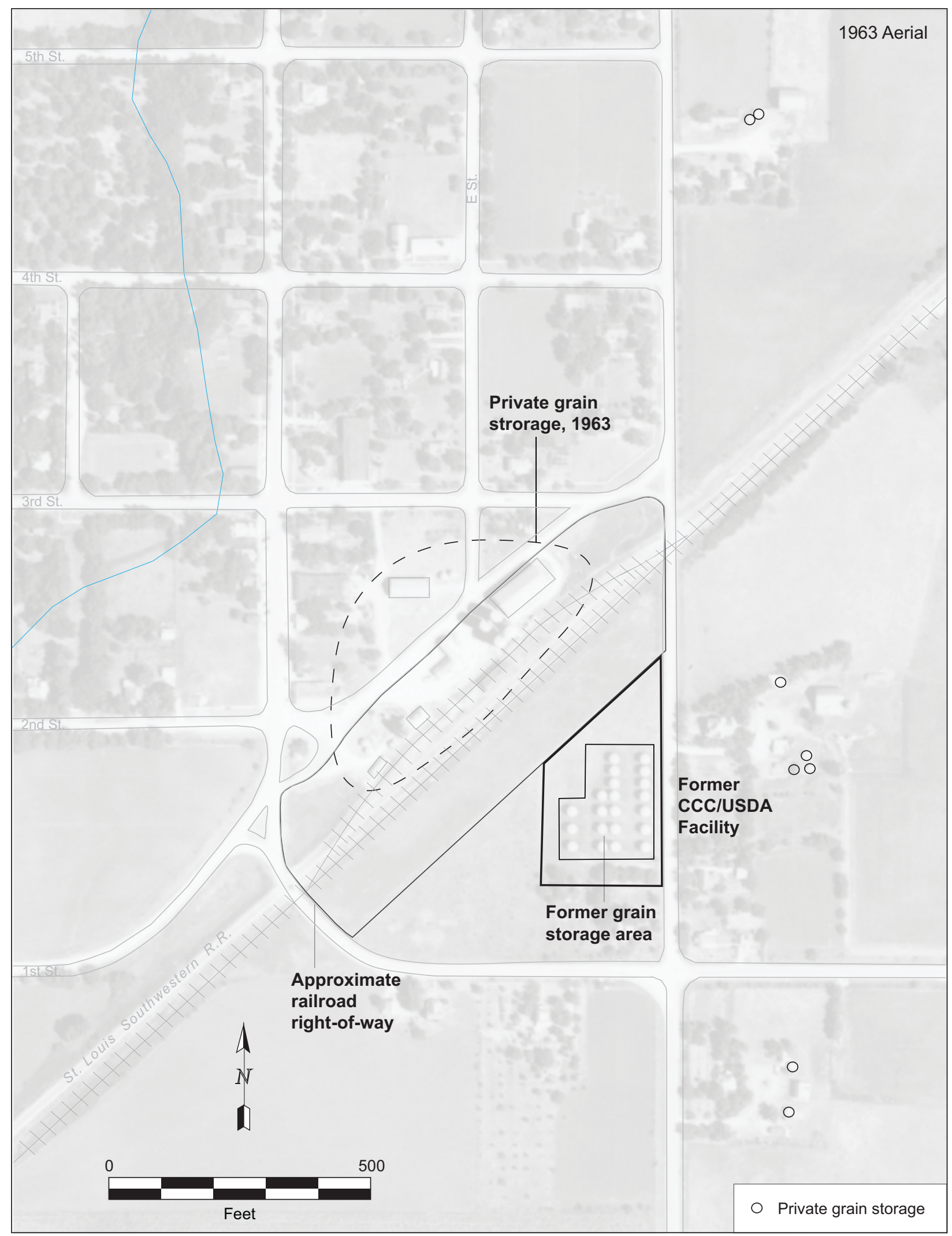

FIGURE 2.2 Locations of former grain storage facilities at Ramona. Source of photograph: USGS (1963). 


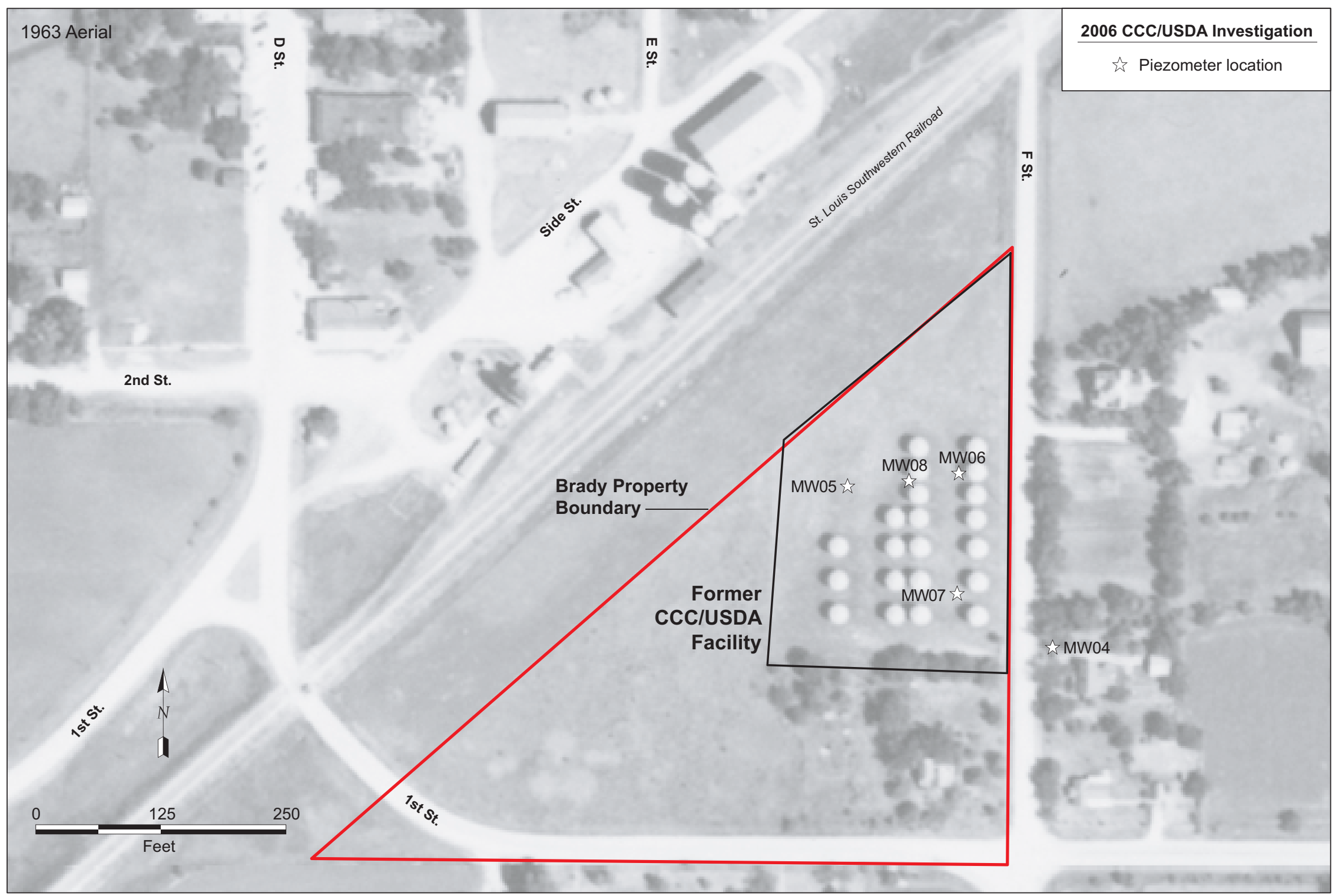

FIGURE 2.3 Boundaries of the former CCC/USDA property and the Brady property. Source of photograph: USGS (1963). 


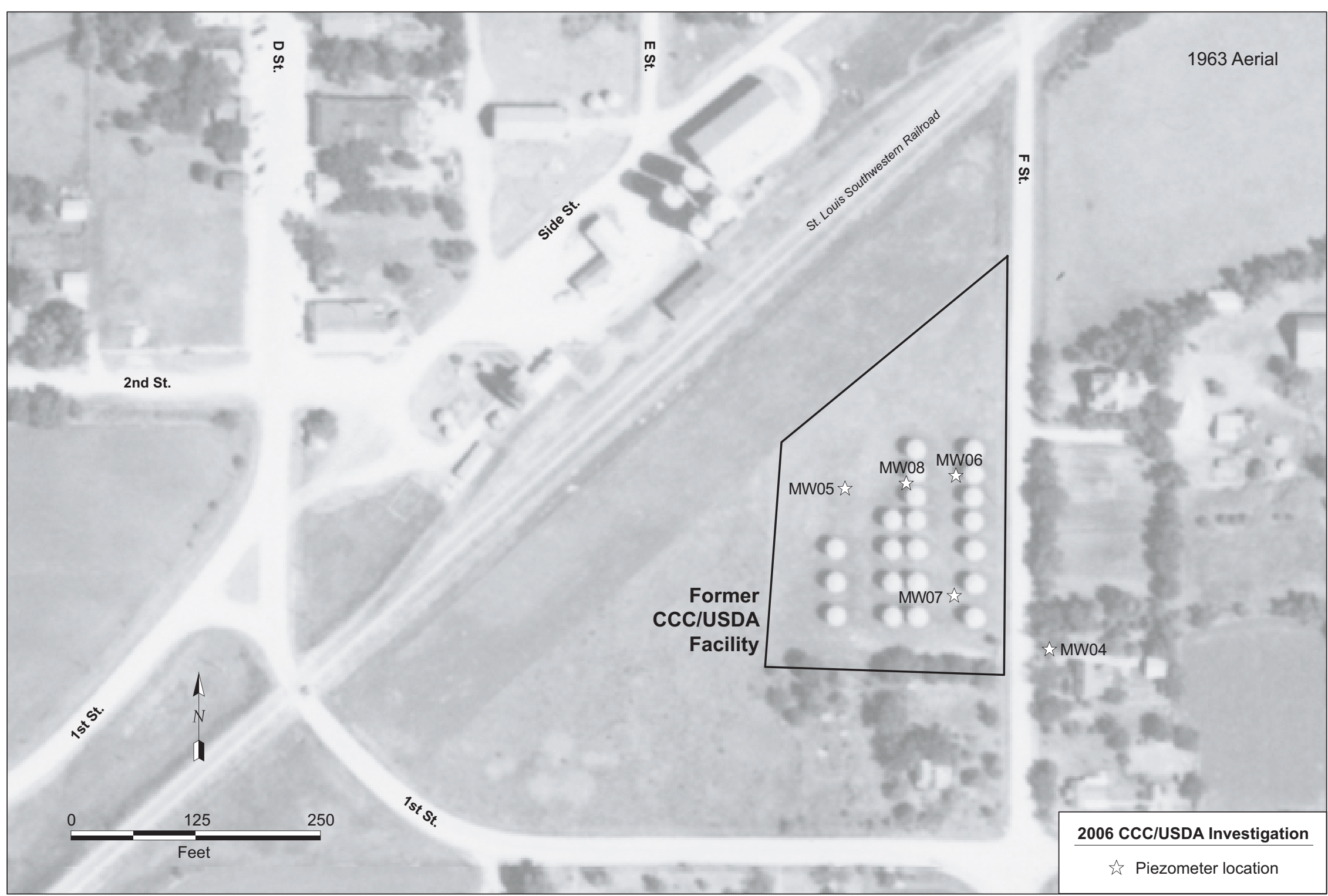

FIGURE 2.4 Locations of permanent piezometers installed by the CCC/USDA in 2006. Source of photograph: USGS (1963). 


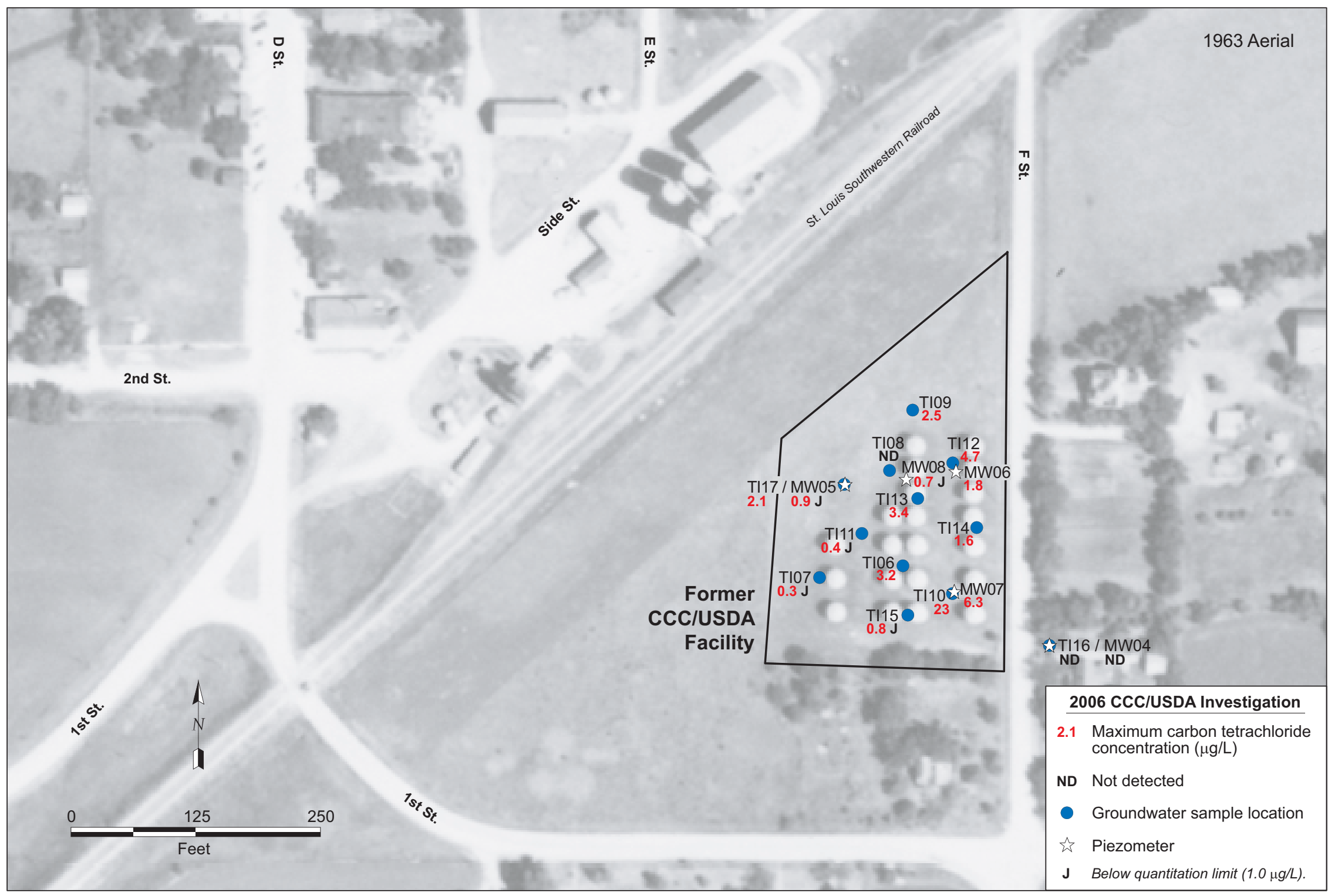




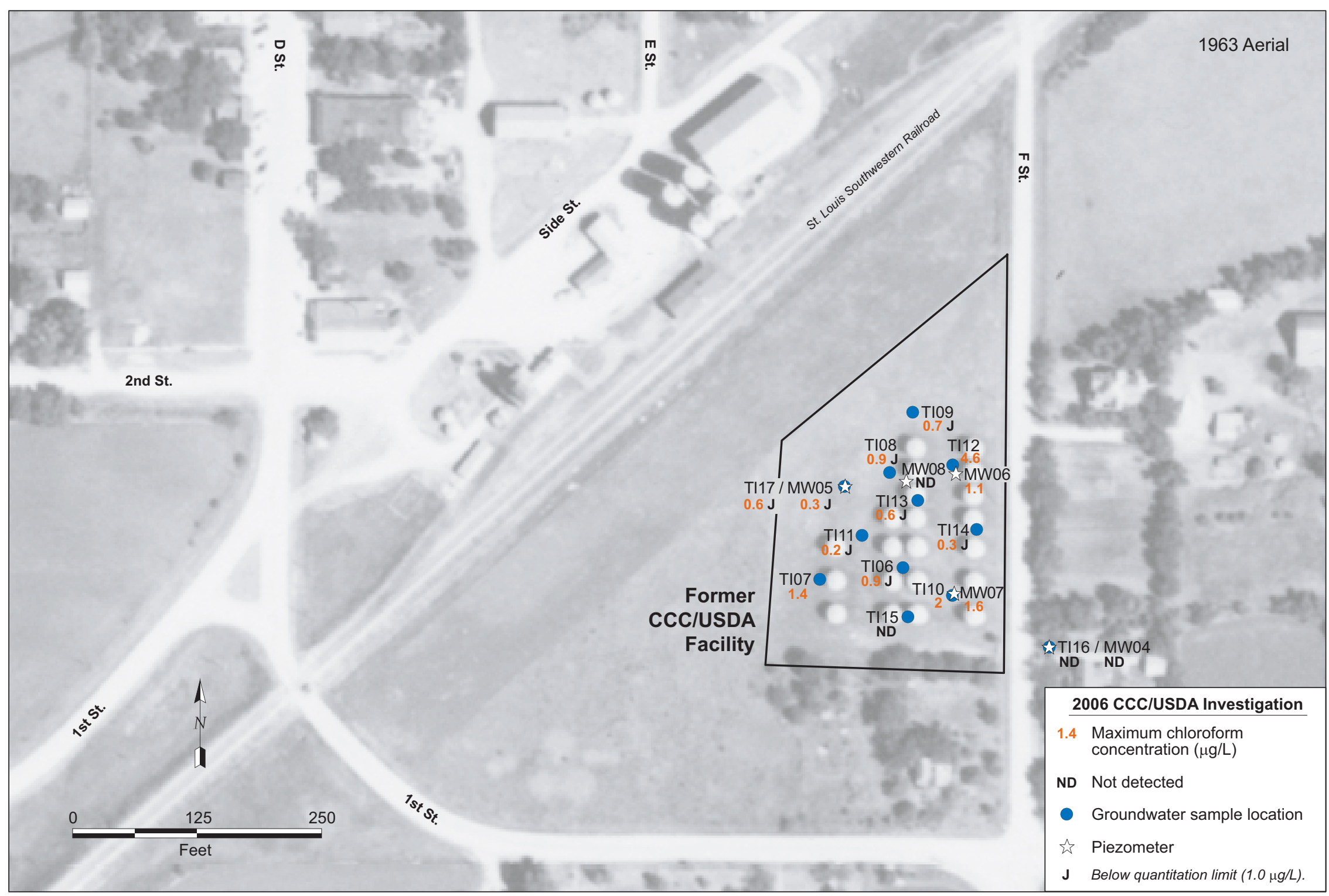




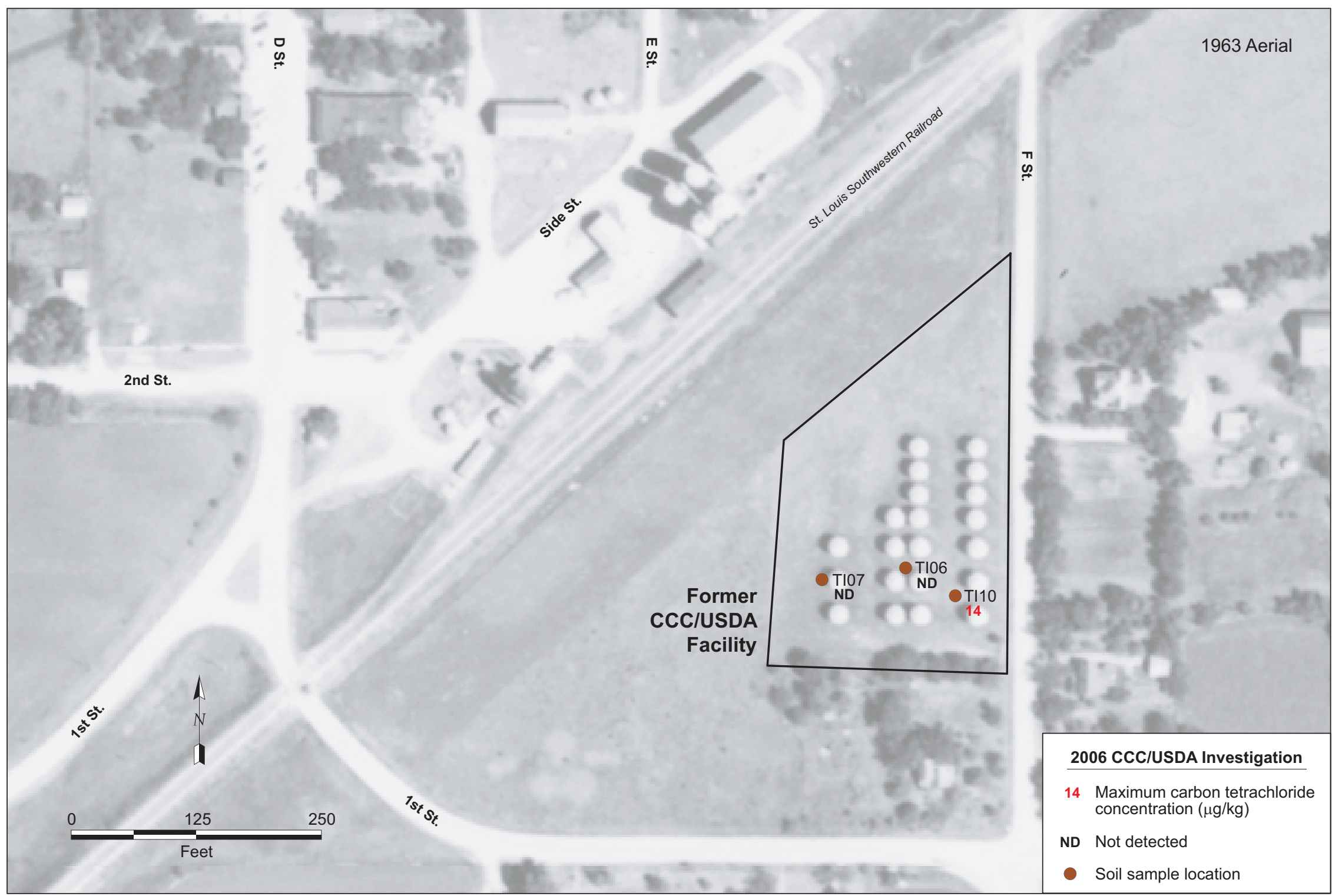

FIGURE 2.7 Maximum concentrations of carbon tetrachloride detected in soil samples collected on the former CCC/USDA property in 2006. Source of photograph: USGS (1963). 


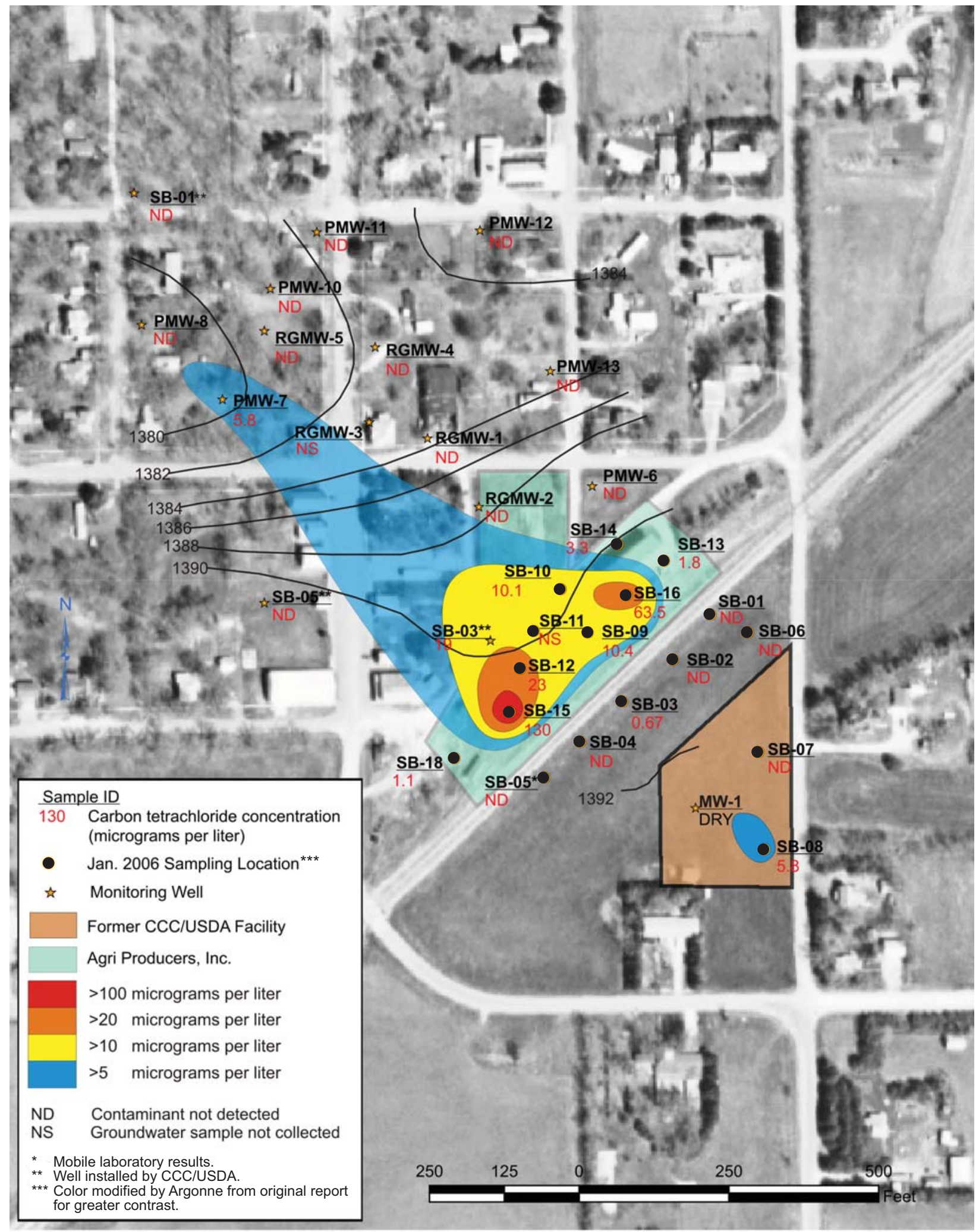

Source of Photograph: USGS (2002)

Map generated by KDHE/BER using ESRI@ ArcGIS v.9.1 and CorelDraw v.13.0.0.576

FIGURE 2.8 Interpreted lateral distribution of carbon tetrachloride in groundwater in the wider area at Ramona, based on results of the KDHE investigation in 2006. 


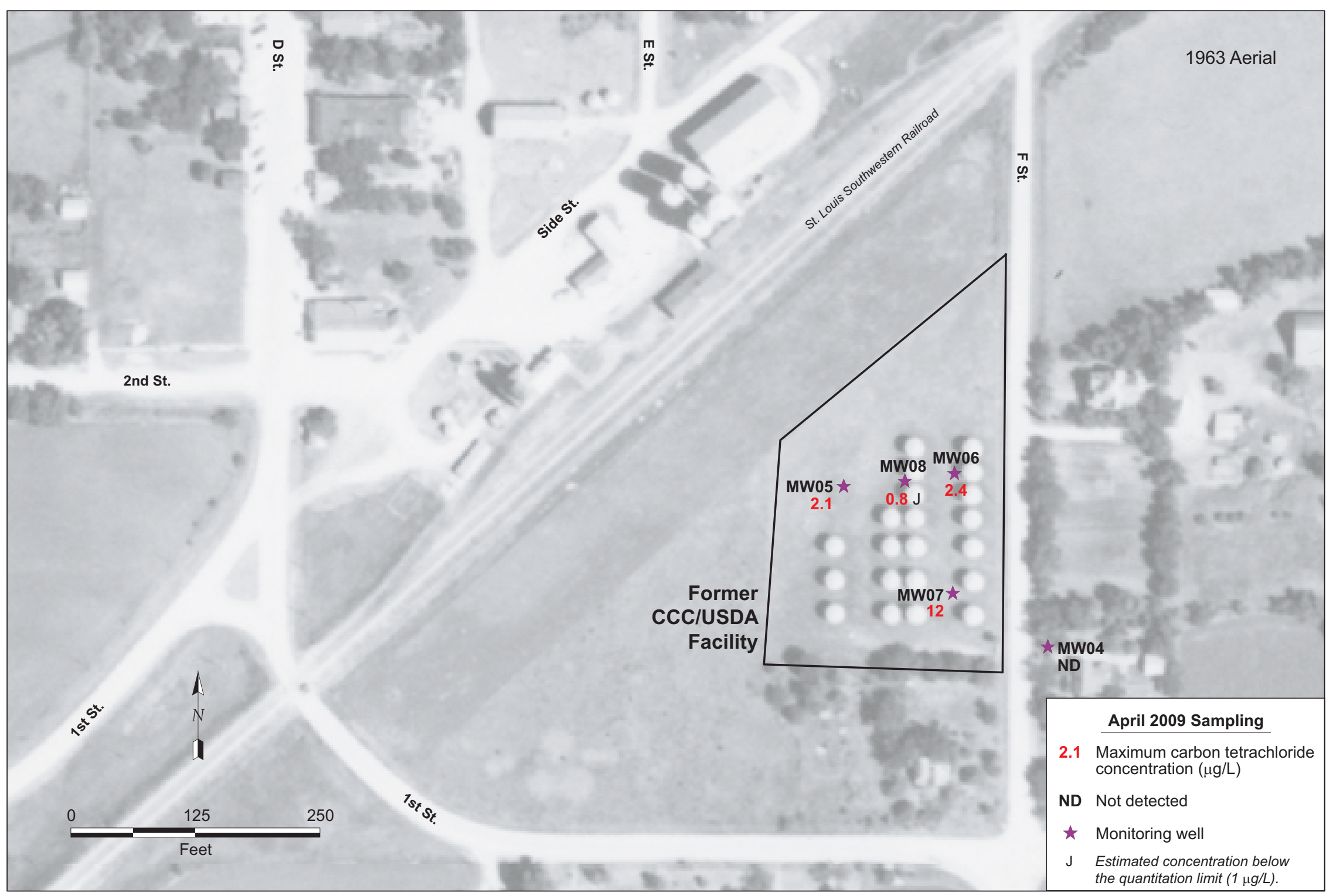

FIGURE 2.9 Maximum carbon tetrachloride concentrations detected in the CCC/USDA groundwater sampling in April 2009. Source of photograph: USGS (1963). 

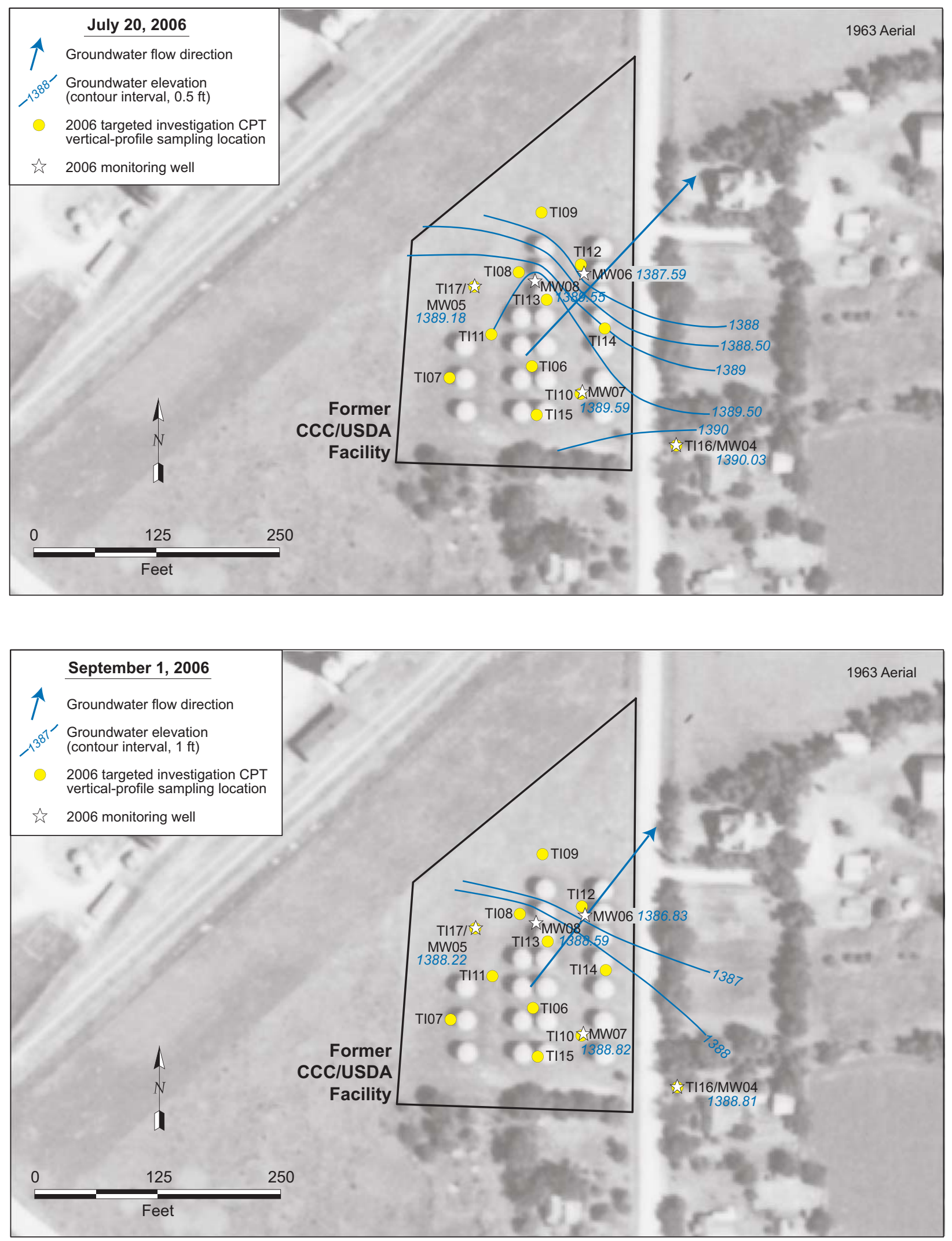

FIGURE 2.10 Potentiometric surface at Ramona, as interpreted from water level measurements made on July 20, 2006, and September 1, 2006. Source of photograph: USGS (1963). 

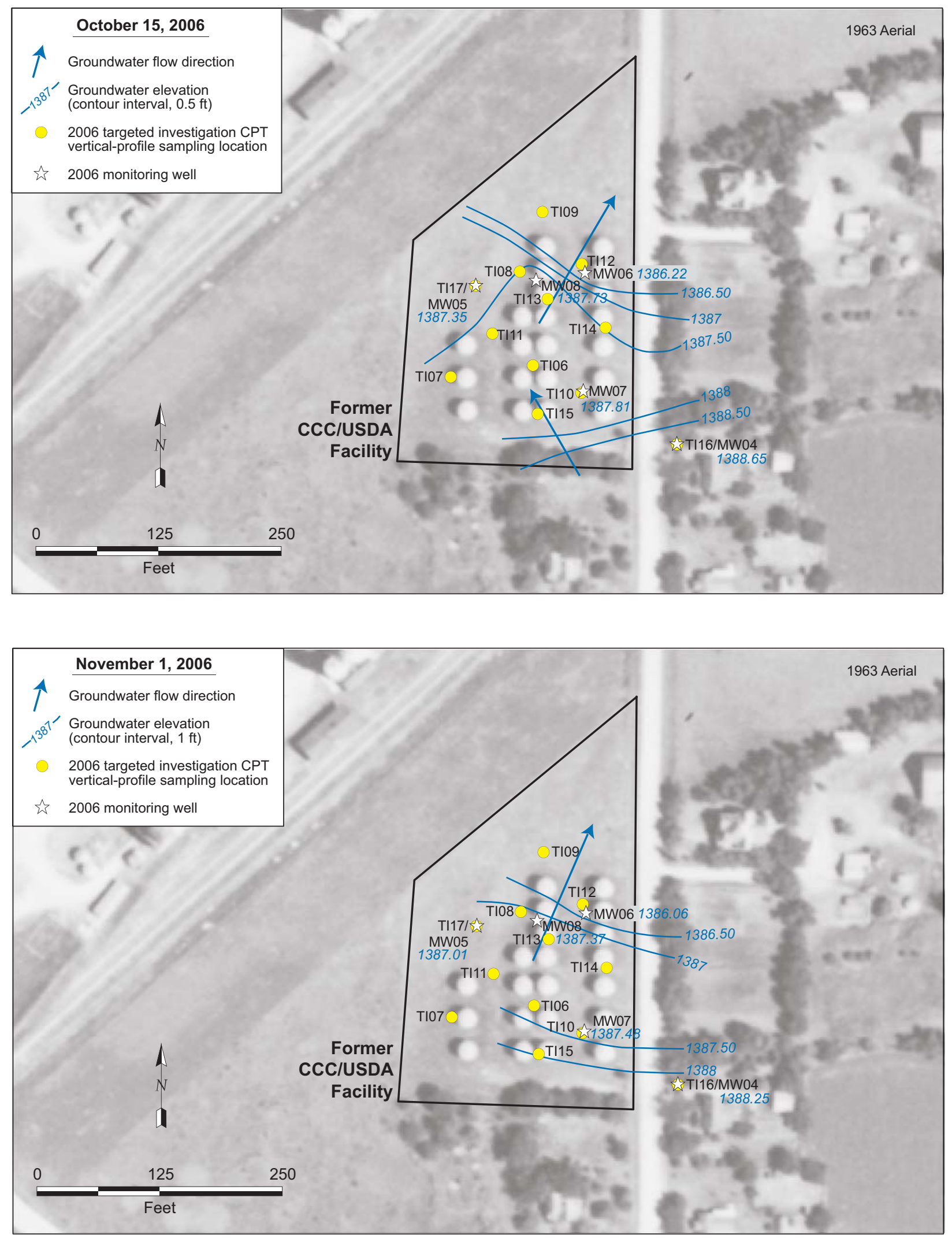

FIGURE 2.11 Potentiometric surface at Ramona, as interpreted from water level measurements made on October 15, 2006, and November 1, 2006. Source of photograph: USGS (1963). 


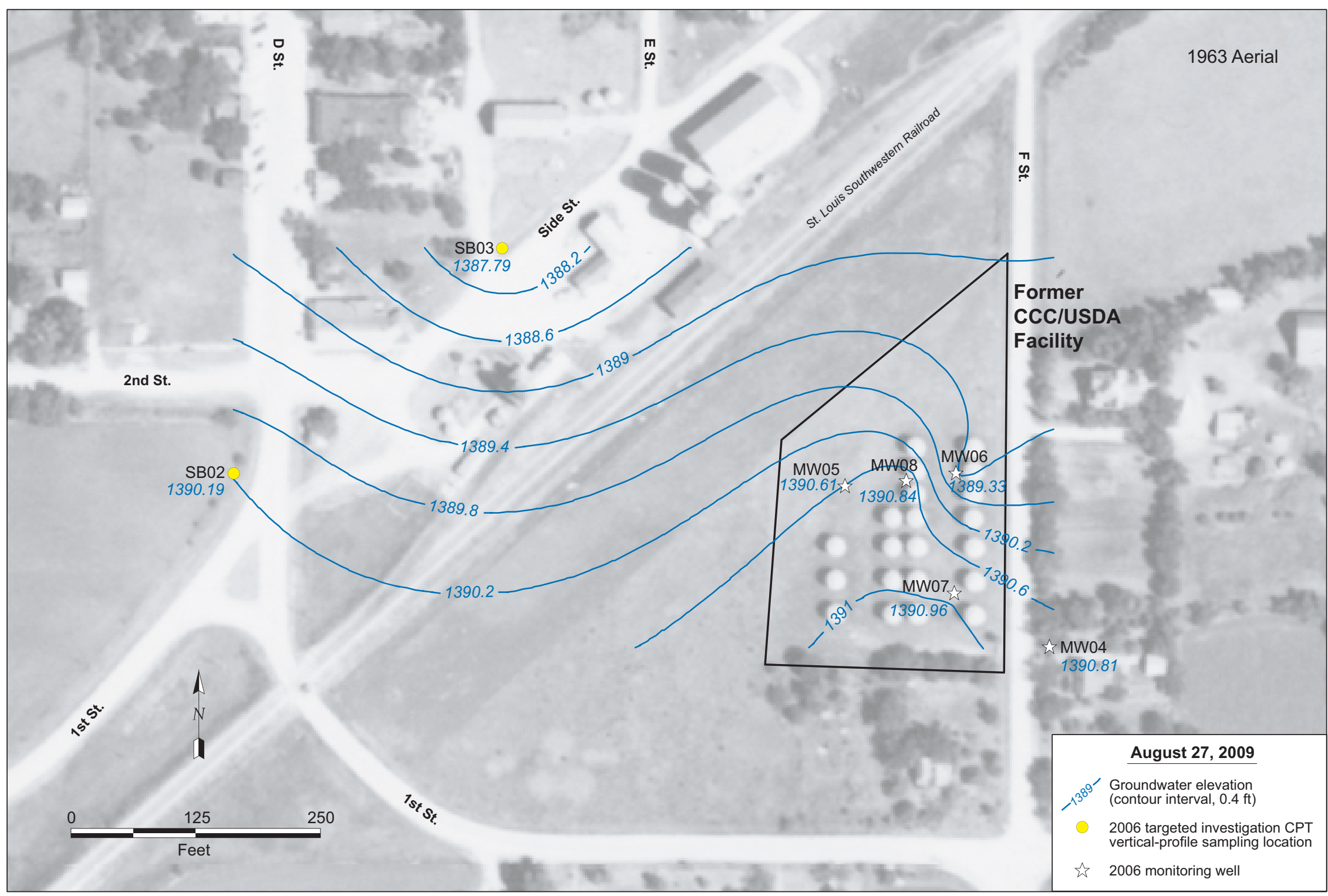

FIGURE 2.12 Water level contours constructed with data measured manually on August 27, 2009. Source of photograph: USGS (1963). 
Ramona, KS Recorder Data

1/1/08 - 9/8/09

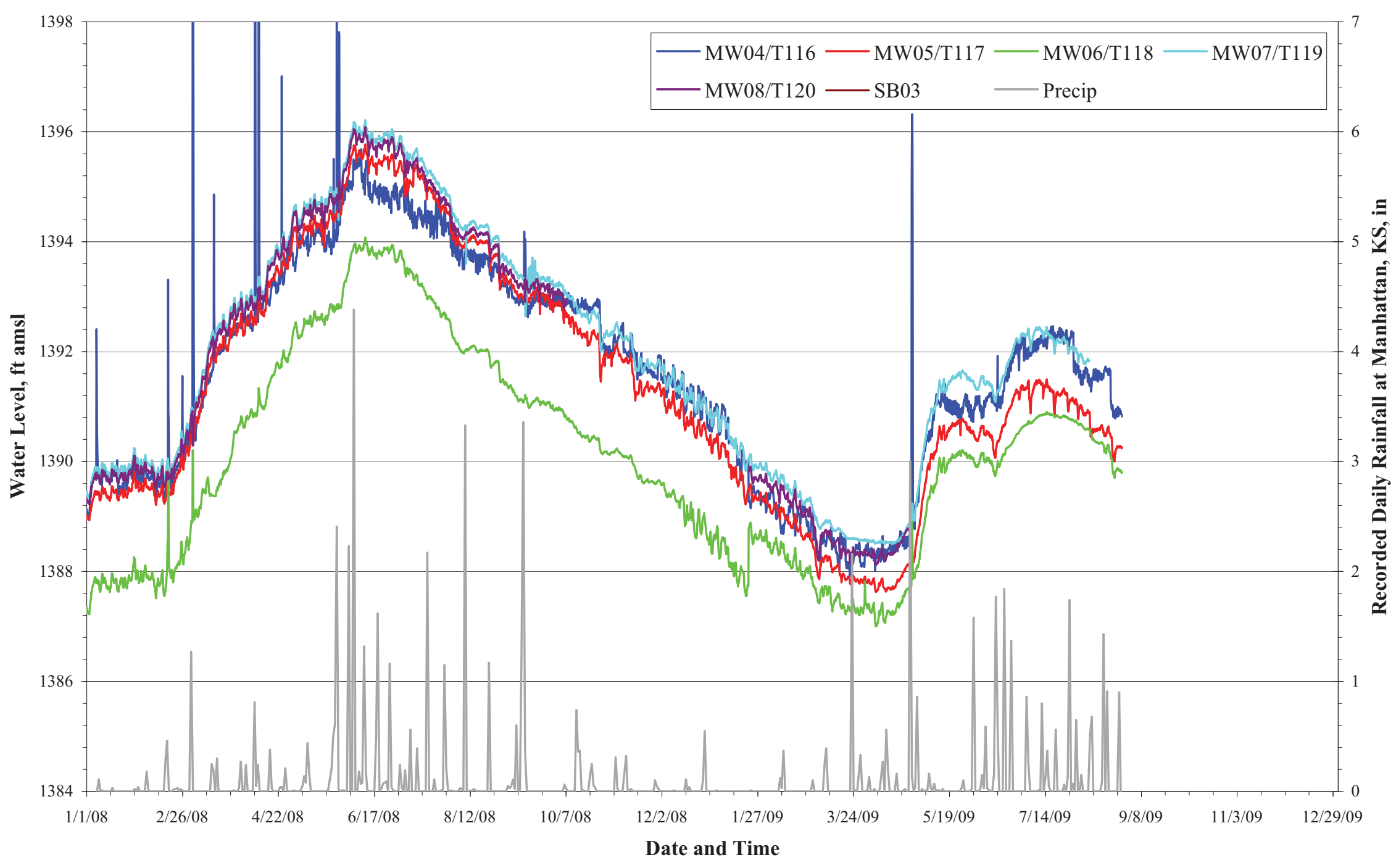




\section{Corrective Action Goals}

\subsection{Site-Specific Goals}

The site-specific goals of any proposed remedial action at the former CCC/USDA facility concern groundwater. These goals are as follows:

- To prevent exposure of human receptors to a water supply derived from groundwater that is contaminated with carbon tetrachloride at concentrations exceeding the RBSL and MCL values of $5 \mu \mathrm{g} / \mathrm{L}$.

- To accomplish reduction of the carbon tetrachloride concentrations below the RBSL and MCL values of $5 \mu \mathrm{g} / \mathrm{L}$.

\subsection{Regulatory Considerations}

\subsubsection{Applicable or Relevant and Appropriate Requirements and Guidance to be Considered}

The KDHE guidance for the preparation of a CAS (KDHE 2001a) lists "compliance with Federal and State applicable, or relevant and appropriate requirements (ARARs)" as one of the criteria that must be evaluated in the CAS process. The CAS guidance also refers to and adopts several regulations and guidance documents related to the Comprehensive Environmental Response, Compensation, and Liability Act (CERCLA). Section 121 of CERCLA and provisions of the National Oil and Hazardous Substances Pollution Contingency Plan (the NCP; EPA 1990) require the EPA to ensure that cleanup actions implemented under CERCLA meet the specifications of ARARs. Applicable requirements are cleanup standards, standards of control, and other substantive environmental protection requirements, criteria, or limitations promulgated under federal or state environmental or facility siting laws that specifically address a hazardous substance, pollutant, contaminant, remedial action, location, or other circumstance. Only those state standards that are identified by a state in a timely manner and that are more stringent than federal requirements may be applicable. 
Relevant and appropriate requirements are cleanup standards, standards of control, and other substantive environmental protection requirements, criteria, or limitations promulgated under federal or state environmental or facility siting laws that, while not attaining the status of being "applicable" to a hazardous substance, pollutant, contaminant, remedial action, location, or other circumstance, nevertheless address problems or situations sufficiently similar so that their use is well suited to the particular site. Only those state standards that are identified by a state in a timely manner and that are more stringent than federal requirements may be relevant and appropriate.

As described by the EPA (1990), ARARs can be placed in three categories: chemicalspecific, location-specific, and action-specific. Chemical-specific ARARs address certain chemical species or classes of contaminants and relate to the allowable limits of contaminant concentrations in various environmental media (soil, groundwater, surface water, air). These ARARs can be used to determine cleanup levels. Location-specific ARARs are based on the specific setting and nature of the site, such as proximity to wetlands, floodplains, or archaeological resources. Action-specific ARARs relate to specific response actions (e.g., excavation or treatment activities) proposed for implementation at the site.

In addition to ARARs, the NCP (EPA 1990) provides for the use of other advisories, criteria, or guidance "to be considered" (TBC). The TBCs are advisories, criteria, and standards that are issued by the federal or state regulatory body but are not legally binding because they have not been promulgated. The identification of TBCs is not mandatory; however, they are to be used, as appropriate, to complement the ARARs.

Potential ARARs for the proposed actions described in Sections 4, 5, and 6 were identified on the basis of the nature of the contamination, the site location, and the proposed activities. A comprehensive list of potential location- and action-specific ARARs and TBCs, including both federal and Kansas requirements, is in Appendix A.

Cleanup levels are generally established on the basis of chemical-specific ARARs, which are requirements or risk-based numerical limits establishing the allowable amount or concentration of a hazardous substance that may exist in or be released to the environment. The contaminant of concern in this case is carbon tetrachloride, and a potential chemical-specific ARAR would be the Kansas-administered Federal Safe Drinking Water Regulations, which 
establish MCLs pertaining to public water supplies as potential ARARs. The MCL for carbon tetrachloride is $5 \mu \mathrm{g} / \mathrm{L}$, as is the Kansas Tier 2 RBSL.

Other Kansas action-specific TBC guidance includes several KDHE Bureau of Environmental Remediation policies (KDHE 2001b, 2002, 2005c,d,e). In addition, the county's Sanitation Code (Marion County 1994), which establishes requirements for groundwater supplies, well installation practices, and private and public water supplies, is a TBC for this Ramona CAS.

\subsubsection{Voluntary Environmental Use Controls}

A voluntary program that could be applied to the former CCC/USDA facility is the Kansas Environmental Use Control (EUC) program (KDHE 2009b). The EUC program was established by Kansas House Bill 2247 (Kansas 2003), which became law on April 21, 2003. An EUC is defined as an institutional or administrative control - a restriction, prohibition, or control - for one or more uses of, or activities on, a specific property. The EUC is requested by a property owner to ensure future protection of public health and the environment when environmental contamination exceeding standards for unrestricted use remains on the property. Obtaining an EUC involves completing an application that details property information, applicant information, the nature of the potential contamination, requested restrictions, and a signature by the site owner or a designated representative. As part of the EUC, the applicant must agree to register an approved, notarized EUC agreement with the register of deeds in the county in which the property is located. The EUC can be removed if contamination is reduced below environmental standards.

As explained in the EUC guidance (KDHE 2009b, pages 150-151), EUC sites are classified in one of three categories, on the basis of property size, the toxicity and mobility of residual contamination, and necessary KDHE inspection frequency. The approval of an EUC agreement involves either a one-time payment to the KDHE or a long-term care (LTC) agreement with the KDHE. Category 1 sites have a one-time payment of $\$ 2,000$, while Category 2 sites have a one-time payment not to exceed $\$ 10,000$. The LTC agreement required for Category 3 sites can be funded at the outset or as costs are incurred by the KDHE (KDHE 2009b [pages 151-152], 2010a,b). 


\subsubsection{Waivers and Variances}

Remedial alternatives that do not meet the requirements of an ARAR may qualify for a waiver or variance. Waivers apply only to the attainment of the ARAR; other statutory requirements (e.g., that remedies be protective of human health and the environment) cannot be waived (CERCLA $\S 121[\mathrm{~d}][4])$. The waivers provided in this guidance are as follows:

- Interim Remedy. An interim remedy action will not attain all ARARs. The interim remedy must be followed by a complete measure that will attain all ARARs.

- Equivalent Standard of Performance. Equivalent or better results can be obtained by using a design or method different from that specified in the ARAR.

- Greater Risk. Compliance with an ARAR will cause greater risk to human health and the environment than noncompliance.

- Technical Impracticability. Achieving an ARAR(s) is impracticable from an engineering perspective.

- Inconsistent Application of State Requirements. Regarding a state standard, requirement, criterion, or limitation, the state has not consistently applied (or demonstrated the intention to apply consistently) the standard, requirement, criterion, or limitation in similar circumstances for other remedial actions.

- Fund Balancing. The costs associated with meeting an ARAR to obtain an added degree of protection or decrease in risk would jeopardize the funds for remedial actions at other sites.

Waivers and variances do not apply at the present time. 


\section{Description of Alternatives}

Corrective action alternatives for the former Ramona CCC/USDA facility were developed by identifying remedial technology types and process options that are potentially applicable for groundwater contaminated with VOCs. The technology types and process options considered were screened for applicability to the site in accordance with EPA (1988) and KDHE (2001a, 2007c, 2009a) guidance.

\subsection{Alternative 1: No Action}

The no-action response is a required component of the CAS evaluation under KDHE (2001a) guidance, to provide a baseline for comparison. The no-action response is evaluated as Alternative 1 in Sections 5 and 6.

Under this alternative, no action would be taken at the former CCC/USDA facility, and the contaminated groundwater would remain in place. As discussed in Section 2.5.1, institutional control measures, including constraints established by the county's Sanitation Code (Marion County 1994) for unincorporated areas of the county with respect to well installation, permitting, and connecting to RWD \#1, would remain in effect.

The former CCC/USDA facility would continue to be an agricultural resource.

\subsection{Alternative 2: Monitoring}

Alternative 2 involves monitoring pending reclassification of the site, with the expectation that water quality would improve and natural degradation would occur over the monitoring time frame. This alternative would involve the sampling and analysis of groundwater from the existing monitoring well network. Results would be reported to the KDHE after each monitoring event. The duration of Alternative 2 is assumed to be $10 \mathrm{yr}$. Monitoring would occur in years $1,2,3,5$, and 10. If monitoring results in years 1 and 2 indicate an improvement in water quality, the CCC/USDA and the KDHE could agree to omit the year 3 monitoring event. Sampling and analysis would continue until groundwater remediation levels were achieved. Alternative 2 would have the following components: 
- Sampling, analysis, and reporting for monitoring wells MW04, MW05, MW06, MW07, and MW08 in years 1, 2, 3 (if needed), 5, and 10.

- Two five-year reviews.

Samples from the five monitoring wells would be analyzed for field parameters $(\mathrm{pH}$, temperature, and conductivity) at the wellhead and for carbon tetrachloride, chloroform, and methylene chloride by a qualified laboratory. Results would be reported to the KDHE after each sampling event. In addition, the CCC/USDA would perform two 5-yr reviews to substantiate that Alternative 2 continues to be protective of human health and the environment.

\subsection{Alternative 3: Environmental Use Controls}

Alternative 3 involves the establishment of an EUC. Implementation of an EUC would require the agreement of the private owner of the former CCC/USDA property. The duration of Alternative 3 is assumed to be $10 \mathrm{yr}$.

Alternative 3 would involve the following components:

- Assisting the land owner in obtaining a Category 2 EUC.

- EUCs including a restriction on the drilling or use of water wells for domestic consumption or other purposes.

- Monitoring of the existing well network for the duration and frequency discussed for Alternative 2 (Section 4.2). Monitoring and reporting would occur in years 1, 2, 3 (if needed), 5, and 10 .

- Two five-year reviews.

For the purposes of Alternative 3, the former CCC/USDA facility must be classified as a Category 1, 2, or 3 property. Category determinations are the sole purview of the KDHE, but they typically are based on the size of the property, the toxicity and mobility of the residual contamination left on the site, and the necessary inspection frequency. For planning and 
budgeting purposes, the former CCC/USDA facility is tentatively being considered a Category 2 site. The EUC agreement for a Category 2 site requires one-time payment by the applicant, not to exceed $\$ 10,000$, to fund the life of the EUC. The EUC would remain in place until rescinded by the KDHE (2009a). The CCC/USDA would assist the landowner in obtaining the KDHE EUC Application to Participate (KDHE 2007d) and would pay the agreement fees.

If the KDHE determines that the subject property is eligible for an EUC agreement, the applicant will be asked to sign the agreement describing the voluntary restrictions requested, will register the agreement with the county, and will submit a notarized copy to the KDHE within 90 days of KDHE approval of the application. The voluntary restrictions that are recommended are as follows:

- The owner will not allow water wells to be drilled, constructed, or used on the property for domestic, lawn, or garden use or other purposes that involve or might involve human consumption and/or other possible human contact. This restriction does not prohibit drilling, construction, or use of water wells for the purpose of hydraulically containing contamination, or for contaminated groundwater recovery, monitoring, or other corrective action activities approved in writing by the KDHE. The KDHE might determine that the EUC limitation applies only to the installation of a well meant for human consumption or domestic use. In this case, the EUC would not apply to a well installed for uses like irrigation or agriculture.

- The owner will agree to preserve, protect, and replace, as necessary, all permanent survey markers and benchmarks and will agree to afford access to the site for monitoring purposes.

The consumption of contaminated groundwater is a potential exposure pathway. For the purposes of this CAS, the restriction of groundwater usage for domestic or other purposes is considered appropriate, as is an EUC restricting the drilling or use of water wells for domestic and perhaps for other purposes. 


\subsection{Alternative 4: In Situ Chemical Reduction}

Alternative 4 would involve treatment with in situ chemical reduction (ISCR) technology in well MW07, which contains contamination above the RBSL and MCL values of $5 \mu \mathrm{g} / \mathrm{L}$. The ISCR treatment would be coupled with monitoring activities to assess effectiveness. An ISCR technology such as the Adventus (http://www.adventusgroup.com/) product $\mathrm{EHC}^{\circledR}$ could be delivered via the A-SOX ${ }^{\mathrm{TM}}$ system (Adventus 2008) placed in the well MW07.

The CCC/USDA pilot tested the Adventus EHC $^{\circledR}$ product, delivered by injection, at Centralia, Kansas (Argonne 2009). The results demonstrated a decrease in carbon tetrachloride concentrations, especially near the borings where the product was injected. At Centralia, difficulties with injecting the material required the use of greater pressures than anticipated and resulted in emergence of the EHC material at the surface. In view of the low concentrations and limited areal distribution of carbon tetrachloride at Ramona, in-well delivery of the material (for example, via the A-SOX system), is considered more suitable than injection.

For the EHC material, the radius of influence of the A-SOX delivery system is roughly estimated (in general) at $10 \mathrm{ft}$ radially and 20-50 ft downgradient (GWP 2010). The longevity of the EHC material in this application is estimated as 3-6 months (Adventus 2008). (Note that the results of the pilot test of injected EHC material at Centralia indicate a longer period of effectiveness in that application.) The material can be replaced as needed. The evaluation here assumes one treatment in the first year, followed by monitoring to substantiate a decrease in carbon tetrachloride concentrations below the RBSL and MCL values of $5 \mu \mathrm{g} / \mathrm{L}$. The duration of Alternative 4 is assumed to be $5 \mathrm{yr}$ (in contrast to the $10 \mathrm{yr}$ assumed for Alternatives 2 and 3).

To verify the effectiveness of the treatment system, two new performance monitoring wells would be installed downgradient from well MW07. One new well is proposed very near the MW07 location; well MW07 will be unavailable for sampling during in-well treatment. The tentative location for the other new monitoring well is proposed on the basis of the inferred limited radius of influence of the ISCR treatment as indicated by GWP (2010), as well as the apparent direction of groundwater flow. The proposed new monitoring locations are depicted in Figure 4.1. The tentative locations are intended as relatively near and relatively far observation points in the expected direction of groundwater flow. The locations were selected with consideration of the expected radius of influence of the in-well treatment (GWP 2010), as discussed above. 
Alternative 4 would include the following components:

- Implementation of the ISCR treatment in well MW07.

- Installation of two new wells to monitor the performance of the ISCR treatment.

- Annual monitoring for existing wells MW05, MW06, MW07, and MW08.

- Treatment area monitoring for the two newly installed wells and existing well MW04, as follows:

- Quarterly in year 1

- $\quad$ Twice annually in year 2

- $\quad$ Annually in years 3-5 
TABLE 4.1 Characteristics and costs of Alternatives 1-4, for $10 \mathrm{yr}$ (Alternatives 2 and 3) or $5 \mathrm{yr}$ (Alternative 4) of implementation.

\begin{tabular}{|c|c|c|c|c|c|c|c|}
\hline \multirow[b]{2}{*}{$\begin{array}{l}\text { Duration } \\
\text { (yr) }\end{array}$} & \multicolumn{7}{|c|}{ Cost (\$ current year) } \\
\hline & Capital and Design & $\begin{array}{c}\text { Operations } \\
\text { and } \\
\text { Maintenance }\end{array}$ & \multicolumn{2}{|c|}{ Monitoring and/or EUCs } & $\begin{array}{l}\text { Five-Year } \\
\text { Review(s) }\end{array}$ & $\begin{array}{c}\text { Closeout } \\
\text { Documentation }\end{array}$ & Total $^{\mathrm{a}}$ \\
\hline \multicolumn{8}{|c|}{ Alternative 1: No Action } \\
\hline- & None & None & None & & None & None & 0 \\
\hline \multicolumn{8}{|c|}{ Alternative 2: Monitoring (10 yr) } \\
\hline 10 & None & None & Monitoring (yr 1, 2, 3, 5, 10): & 85,000 & $47,000(2)$ & 10,000 & 142,000 \\
\hline \multicolumn{8}{|c|}{ Alternative 3: Environmental Use Controls (10 yr) } \\
\hline 10 & None & None & $\begin{array}{l}\text { Monitoring (yr 1, 2, 3, 5, 10): } \\
\text { EUCs: }\end{array}$ & $\begin{array}{l}85,000 \\
10,000\end{array}$ & $47,000(2)$ & 10,000 & 152,000 \\
\hline \multicolumn{8}{|c|}{ Alternative 4: In Situ Chemical Reduction (5 yr) } \\
\hline 5 & $\begin{array}{l}\text { Capital: } 22,000 \\
\text { Design: } 5,000\end{array}$ & None & $\begin{array}{l}\text { Monitoring: } \\
\text { Year 1: MW05, MW06, MV } \\
\text { - } 1 \text { time; MW04 and } 2 \\
4 \text { times. } \\
\text { Year 2: MW05, MW06, MV } \\
\text { - } 1 \text { time; MW04 and } 2 \\
2 \text { times. } \\
\text { Years 3, 4, 5: MW04, MW } \\
\text { MW07, MW08, and } 2 \text { ne } \\
\text { time. }\end{array}$ & $\begin{array}{l}\text { 136,000 } \\
\text { MW08 } \\
\text { wells - } \\
\text { MW08 } \\
\text { wells - } \\
\text { Mw06, } \\
\text { vells - } 1\end{array}$ & $23,000(1)$ & 10,000 & 196,000 \\
\hline
\end{tabular}

a Net present value costs (see Section 5.2.7) are as follows:

Alternative 1 (no action):

Alternative 2 (monitoring): $\quad \$ 116,000$

Alternative 3 (EUCS): $\quad \$ 126,000$

Alternative 4 (ISCR): $\quad \$ 177,000$ 
TABLE 4.2 Monitoring, reporting, and review tasks for Alternative 2 (monitoring; $10 \mathrm{yr}$ ).

\begin{tabular}{llc}
\hline \multicolumn{1}{c}{ Task } & \multicolumn{1}{c}{$\begin{array}{c}\text { Description } \\
\text { Devents } \\
\text { in Ten Years }\end{array}$} \\
\hline Sampling and analysis for five wells & Years 1, 2, 3, 5, 10 & 5 \\
Water level measurements & Continuous, automatic, with annual downloads & 10 \\
$\begin{array}{l}\text { Results reporting to KDHE } \\
\text { Remedy review }\end{array}$ & Years 1, 2, 3, 5, 10 & 5 \\
Closeout & Five-year reviews & 2 \\
& Closeout documentation & 1 \\
\hline
\end{tabular}

TABLE 4.3 Monitoring, reporting, and review tasks for Alternative 3 (EUCs; 10 yr).

\begin{tabular}{|c|c|c|}
\hline Task & Description & $\begin{array}{c}\text { Total Events } \\
\text { in Ten } \\
\text { Years }\end{array}$ \\
\hline Sampling and analysis for five wells & Years $1,2,3,5,10$ & 5 \\
\hline Water level measurements & Continuous, automatic, with annual downloads & 10 \\
\hline Results reporting to $\mathrm{KDHE}$ & Years 1, 2, 3, 5, 10 & 5 \\
\hline Remedy review & Five-year reviews & 2 \\
\hline Closeout & Closeout documentation & 1 \\
\hline
\end{tabular}

TABLE 4.4 Treatment, monitoring, reporting, and review tasks for Alternative 4 (ISCR treatment; 5 yr).

\begin{tabular}{|c|c|c|}
\hline Task & Description & $\begin{array}{l}\text { Total Events } \\
\text { in Five Years }\end{array}$ \\
\hline ISCR treatment & In-well treatment & 1 (year 1) \\
\hline Monitoring well installation & Two monitoring wells near MW07 & 1 \\
\hline $\begin{array}{l}\text { Sampling and analysis of } 2 \text { new wells } \\
\text { and existing well MW04 }\end{array}$ & $\begin{array}{l}\text { Quarterly in year } 1 \text {, twice annually in year } 2 \text {, and } \\
\text { annually in years 3-5 }\end{array}$ & 9 \\
\hline $\begin{array}{l}\text { Sampling and analysis of } 4 \text { existing wells } \\
\text { (MW05, MW06, MW07, MW08) }\end{array}$ & Annually for $5 \mathrm{yr}$ & 5 \\
\hline Water level measurements & Continuous, automatic, with annual downloads & 5 \\
\hline Results reporting to KDHE & Annually for $5 \mathrm{yr}$ & 5 \\
\hline Remedy review & Five-year review & 1 \\
\hline Closeout & Closeout documentation & 1 \\
\hline
\end{tabular}




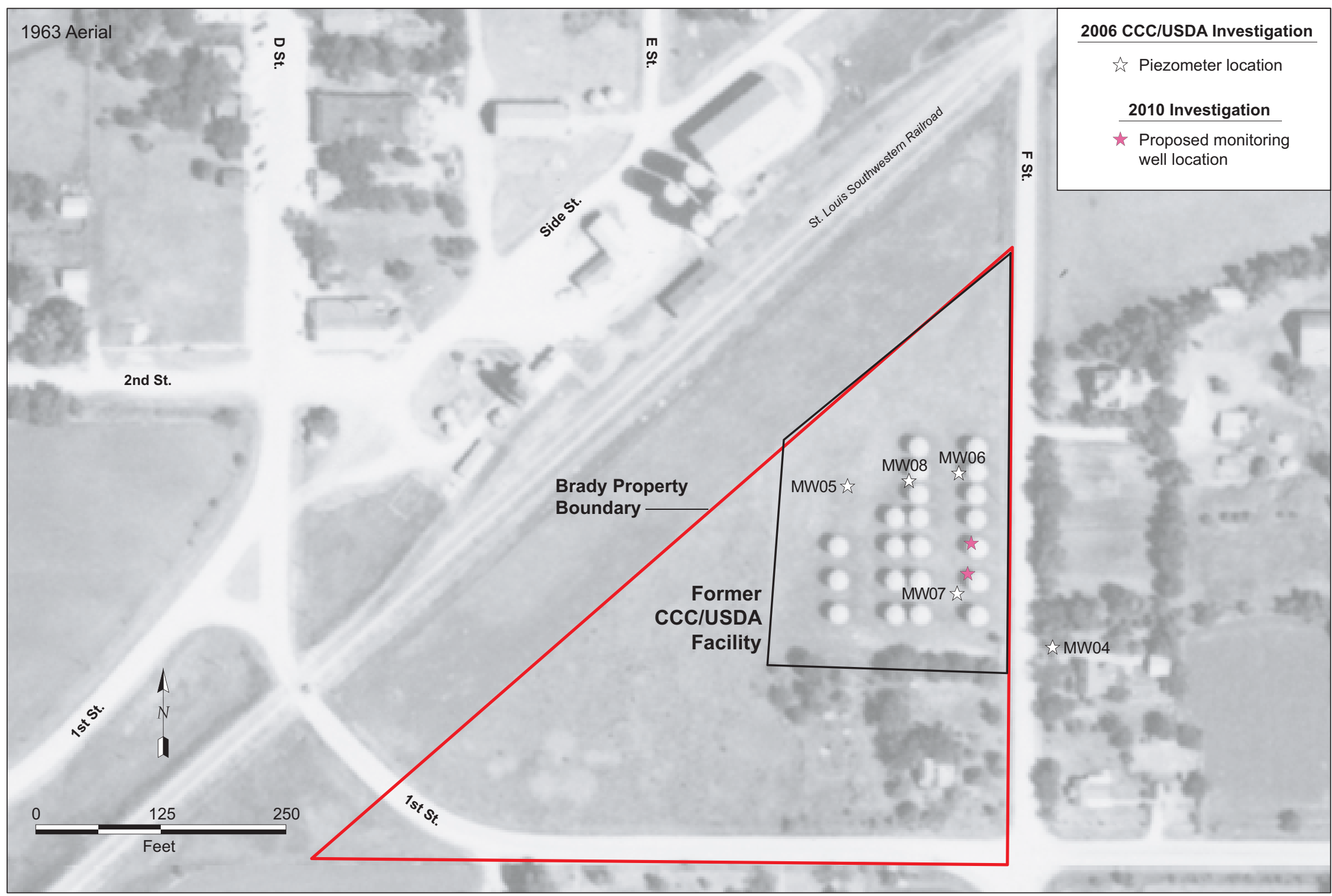

FIGURE 4.1 Proposed well locations for Alternative 4. Source of photograph: USGS (1963). 


\section{Detailed Analysis of Corrective Action Alternatives}

In its CAS guidance, the KDHE (2001a) adopted by reference nine EPA-defined criteria that must be evaluated for each alternative. The criteria are as follows:

1. Overall protection of human health and the environment, which addresses protection from unacceptable risks in both the short term and the long term by minimizing exposures, in accordance with the purpose and objectives of the proposed actions. Because of its broad scope, this criterion also reflects the focus of criteria 2-5.

2. Compliance with ARARs, which addresses the attainment of federal and state environmental requirements determined to be either applicable or relevant and appropriate to the alternative, on the basis of site-specific considerations. Potential ARARs and TBCs are listed in Appendix A.

3. Long-term effectiveness and permanence, which addresses residual risks remaining after completion of a remedial action. The EPA (1991) guidance states that it is usually sufficient to indicate whether an alternative has the potential to achieve the preliminary cleanup levels and not necessary to quantify the risk that would remain after implementation.

4. Reduction of contaminant toxicity, mobility, or volume, which addresses the degree to which treatment addresses the principal threat(s) at the site; the amount of material treated; the magnitude, significance, and reversibility of the given reduction; and the nature and quantity of treatment residuals.

5. Short-term effectiveness, which addresses the potential impacts to site workers, the general public, and the environment from implementing the alternative; the effectiveness and reliability of mitigative measures; and the time required to achieve protection.

6. Implementability, which addresses technical feasibility, including the availability and reliability of required resources (such as specific technologies, materials and equipment, facility capacities, and skilled workers); ease of 
implementation; and the ability to monitor effectiveness. This criterion also addresses administrative feasibility. The actual determination of administrative feasibility would not be made until after the CAS is completed.

7. Cost, which addresses both capital and annual operation and maintenance costs. Costs for the individual components of the alternatives are also considered. Costs presented for all alternatives here were estimated by using the RACER model (AECOM 2009). Additional information about the cost estimates and assumptions used is in Appendix B.

8. State acceptance, which addresses KDHE comments on the alternatives being considered. Groundwater in the Ramona area has been affected by both the Co-op site and operations at the former CCC/USDA facility. In contrast to the contamination scenario at the former CCC/USDA facility, the concentrations of contaminants in groundwater are much higher at the Co-op site, the areal extent of the plume is more expansive, and the impacted groundwater has migrated beneath habitable structures in a residential area. Despite these differences, state acceptance of a given alternative at the former CCC/USDA facility could influence KDHE decisions regarding the Co-op site. Because the KDHE position on groundwater contamination in Ramona overall will not be known until this report has been issued for public review and the corrective action selected, the state acceptance criterion is deferred.

9. Community acceptance, which addresses the comments made by the community on the alternatives being considered. Because these comments will not be received until this report has been issued for public review, the community acceptance criterion is deferred.

In the following sections, each of the four alternatives outlined in Section 4 is evaluated in detail on the basis of criteria 1-7 above. A comparative analysis is presented in Section 6. 


\subsection{Alternative 1: No Action}

In compliance with the CAS requirements (KDHE 2001a), the no-action alternative is included to provide a baseline for comparison with the other alternatives. Under this alternative, no action would be taken at the former CCC/USDA facility.

\subsubsection{Overall Protection of Human Health and the Environment}

Under the current use conditions, Alternative 1 would be considered protective of human health and the environment, because there are no complete exposure pathways to human or ecological receptors. Under future use conditions, even absent any city ordinances restricting the installation of water supply wells in impacted portions of the aquifer, Alternative 1 eventually would be considered protective of human health and the environment in the long term.

\subsubsection{Compliance with ARARs}

Under Alternative 1, the chemical-specific RBSL-MCL value of $5 \mu \mathrm{g} / \mathrm{L}$ is an ARAR that would not be addressed directly and would not be met until natural processes eventually decreased contaminant concentrations to this level, on a time scale that cannot be predicted with any accuracy. Because no active measures are associated with Alternative 1, there are no location- or action-specific ARARs.

\subsubsection{Long-Term Effectiveness and Permanence}

Alternative 1 would involve no treatment of the contaminated groundwater and thus would not be considered permanent. However, contaminant levels will be reduced eventually through natural processes. Under future use conditions, absent any city ordinances restricting the installation of water supply wells in impacted portions of the aquifer, Alternative 1 would not be effective in the long term.

Under Alternative 1, the level of contamination and risks to terrestrial biota over the long term would be similar to current levels. These risks are considered insignificant, because there would be no exposure to the impacted groundwater. 


\subsubsection{Reduction of Toxicity, Mobility, or Volume}

Implementation of Alternative 1 would not directly address the toxicity, mobility, or volume of contaminants at the site; however, contaminant levels are very low at present, and continued intrinsic remediation will result in a long-term decrease in the toxicity and volume of the contaminants present. Lateral mobility of contaminants is limited by the relatively low permeability of the impacted aquifer at the former CCC/USDA facility.

\subsubsection{Short-Term Effectiveness}

Implementation of Alternative 1 would not impact the general public or the environment. No mitigation measures would be required.

\subsubsection{Implementability}

Implementation of Alternative 1 would be straightforward. The former CCC/USDA facility would continue to be used as an agricultural resource.

\subsubsection{Cost}

No costs would be associated with Alternative 1 .

\subsection{Alternative 2: Monitoring}

\subsubsection{Overall Protection of Human Health and the Environment}

Under the current use conditions, Alternative 2 would be considered protective of human health and the environment, because there are no complete exposure pathways to human or ecological receptors. Under future use conditions, even absent city ordinances restricting the installation of water supply wells in impacted portions of the aquifer, Alternative 2 would offer some protection for human health and the environment, in that it would provide an indication of the level of risk that would remain over time as natural processes decrease contaminant levels. 


\subsubsection{Compliance with ARARs}

Under Alternative 2, the chemical-specific RBSL-MCL value of $5 \mu \mathrm{g} / \mathrm{L}$ is an ARAR that would not be addressed directly and would not be met until natural processes eventually decreased contaminant concentrations to this level, on a time scale that cannot be predicted with any accuracy. Alternative 2 would comply with other pertinent ARARs and TBCs as appropriate. No location-specific ARARs and TBCs apply. No archeological or cultural resources are known to exist at the former CCC/USDA facility. No critical ecological habitats have been found at the facility, and activities to implement Alternative 2 are not expected to impact local wetlands or wildlife.

\subsubsection{Long-Term Effectiveness and Permanence}

Alternative 2 would not involve any active treatment of contaminated groundwater at the site. Under future use conditions, absent any city ordinances restricting the installation of water supply wells in impacted portions of the aquifer, Alternative 2 would not be effective as a longterm remedy until contaminant levels were eventually reduced through natural mechanisms. The time required to achieve this reduction might be acceptable to the state and the community, considering the very low levels of contamination that are present.

Under Alternative 2, the level of contamination and risks to terrestrial biota over the long term would be similar to current levels. These risks are considered insignificant, because there would be no exposure to the impacted groundwater.

\subsubsection{Reduction of Toxicity, Mobility, or Volume}

Implementation of Alternative 2 would not directly address the toxicity, mobility, or volume of contaminants; however, contaminant levels are very low at present, and continued intrinsic remediation would result in a long-term decrease in the toxicity and volume of the contaminants present. Lateral mobility of contaminants is limited by the relatively low permeability of the impacted aquifer at the former CCC/USDA facility. 


\subsubsection{Short-Term Effectiveness}

Implementation of Alternative 2 would not affect the general public and the environment. No mitigation measures would be required. Site workers involved in monitoring would be protected by adherence to Argonne's health and safety requirements and the provisions in the Master Work Plan (Argonne 2002) and the site-specific health and safety plan.

\subsubsection{Implementability}

Monitoring and reporting would be performed with readily available resources.

\subsubsection{Cost}

The estimated 10-yr cost for Alternative 2 is $\$ 142,000$ in current-year dollars with markups. Included are costs associated with sampling and analyzing water samples from five wells in years $1,2,3,5$, and 10, with the generation of a report after each sampling event to summarize the results. Costs associated with this monitoring and reporting would be approximately $\$ 85,000$ over $10 \mathrm{yr}$. Two 5-yr reviews would be performed, at a total cost of $\$ 47,000$. If closeout documentation was required, the associated costs would be approximately $\$ 10,000$. The net present value (NPV) of Alternative 2 is $\$ 116,000$. The NPV is the amount that must be to be set aside at the outset to assure that funds are available to meet future needs. The CCC/USDA used a low (conservative) discount rate of $4 \%$ to develop present-value cost estimates for the former CCC/USDA facility in Ramona.

\subsection{Alternative 3: Environmental Use Controls}

\subsubsection{Overall Protection of Human Health and the Environment}

Under current use conditions, Alternative 3 would be considered protective of human health and the environment, because there are currently no complete exposure pathways to human or ecological receptors. Under future use conditions, Alternative 3 would eliminate the potential for exposure to contaminants in groundwater, because the owner would agree to prohibit the installation of a water supply well. 


\subsubsection{Compliance with ARARs}

Under Alternative 3, the chemical-specific RBSL-MCL value of $5 \mu \mathrm{g} / \mathrm{L}$ is an ARAR that would not be addressed directly and would not be met until natural processes eventually decreased contaminant concentrations to this level. Alternative 3 would comply with other pertinent ARARs and TBCs as appropriate. No location-specific ARARs and TBCs apply. No archeological or cultural resources are known to exist at the former CCC/USDA facility. No critical ecological habitats have been found at the facility, and activities to implement Alternative 3 (monitoring and EUCs) are not expected to impact local wetlands or wildlife.

\subsubsection{Long-Term Effectiveness and Permanence}

Alternative 3 would involve no treatment of contaminated groundwater at the site, although contamination will decrease through natural processes. Alternative 3 would, however, be protective of human health and the environment over the long term. The EUCs associated with this alternative would eliminate potential exposure to contaminated groundwater and would remain in force until natural processes decrease the contaminant levels.

\subsubsection{Reduction of Toxicity, Mobility, or Volume}

Implementation of Alternative 3 would not directly address the toxicity, mobility, or volume of contaminants at the site; however, contaminant levels are very low at present, and continued intrinsic remediation will result in a long-term decrease in the toxicity and volume of the contaminants present. Lateral mobility of contaminants is limited by the relatively low permeability of the impacted aquifer at the former CCC/USDA facility.

\subsubsection{Short-Term Effectiveness}

Implementation of Alternative 3 would not affect the general public or the environment. No mitigation measures would be required. Site workers involved in monitoring would be protected by adherence to Argonne's health and safety requirements and the provisions in the Master Work Plan (Argonne 2002) and the site-specific health and safety plan. 


\subsubsection{Implementability}

Alternative 3 would provide an administrative mechanism for the management of risk. For Alternative 3 to be feasible, the site owner would have to agree to the EUC restrictions described in Section 4.3. The absence of active measures to decrease carbon tetrachloride concentrations in groundwater, which are currently above the RBSL and MCL values of $5 \mu \mathrm{g} / \mathrm{L}$, also affects the potential for regulatory acceptance of this alternative.

Implementation of Alternative 3 would be straightforward. The EUC program is mature in the state of Kansas, with more than 30 EUC agreements established. The former CCC/USDA facility would continue to be an agricultural resource. Monitoring and reporting would be performed with readily available resources.

\subsubsection{Cost}

The estimated 10-yr cost of Alternative 3 is approximately $\$ 152,000$ in current-year dollars with markups. Included are costs for sampling and analyzing water samples from five wells in years $1,2,3,5$, and 10, with associated reports to summarize the results after each monitoring event. Costs associated with this monitoring would be approximately $\$ 85,000$ over $10 \mathrm{yr}$. Two 5-yr reviews would be performed, at a total cost of $\$ 47,000$. If closeout documentation was required, the associated costs would be approximately $\$ 10,000$. In addition, a Category 2 EUC permit fee for the KDHE is expected to cost approximately $\$ 10,000$, for a cost of approximately $\$ 152,000$ for the alternative over $10 \mathrm{yr}$. The estimated NPV for Alternative 3 is about $\$ 126,000$.

\subsection{Alternative 4: In Situ Chemical Reduction}

\subsubsection{Overall Protection of Human Health and the Environment}

Under the current use conditions, Alternative 4 would be considered protective of human health and the environment, because there are no complete exposure pathways to human or ecological receptors. The ISCR component of the remedy offers the potential for active reduction of the carbon tetrachloride concentration to levels below the RBSL and MCL values of $5 \mu \mathrm{g} / \mathrm{L}$. 
The ISCR treatment could, however, have a negative impact on groundwater quality, because the chemicals introduced could increase groundwater values for secondary MCLs above acceptable levels.

\subsubsection{Compliance with ARARs}

Under Alternative 4, action would be taken to meet chemical-specific ARARs. The RBSL-MCL value for carbon tetrachloride $(5 \mu \mathrm{g} / \mathrm{L})$ is a chemical-specific ARAR that is exceeded at the site and would be addressed directly. Alternative 4 would comply with other pertinent ARARs and TBCs as appropriate. No location-specific ARARs and TBCs apply. No archeological or cultural resources are known to exist at the former CCC/USDA facility. No critical ecological habitats have been found at the facility, and activities to implement Alternative 4 (monitoring and in-well ISCR treatment) are not expected to impact local wetlands or wildlife.

\subsubsection{Long-Term Effectiveness and Permanence}

Alternative 4 would be protective of human health and the environment over the long term if the ISCR treatment succeeded in bringing the concentration of carbon tetrachloride below the regulatory level and if the chemical additives did not otherwise adversely affect groundwater quality. Alternative 4 would result in a permanent response, since the ISCR treatment would directly and irreversibly address the carbon tetrachloride contamination in groundwater.

As noted for the pilot test at the former CCC/USDA grain storage facility in Centralia, Kansas (Argonne 2009), the ISCR treatment can negatively affect groundwater quality. Groundwater obtained from monitoring points within the injection field at the Centralia pilot site is dark gray to black in color and has a very strong, unpleasant, fetid odor. At Centralia, the injection of relatively large quantities of the ISCR material at multiple surface locations and aquifer depths was required to address high initial concentrations of carbon tetrachloride. In contrast, at Ramona the ISCR treatment proposed is more passive in nature and is applied to an individual well, relying on the diffusion of groundwater through the well screen and the ISCR material hanging in the well for lateral dissipation. Consequently, the treatment proposed at Ramona will affect groundwater contamination in a limited area for an unknown duration. 
The in-well treatment considered suitable for Ramona would involve far less of the ISCR material than the Centralia injection application, in only a localized area. The negative effects on water quality would be expected to be minor in comparison to those observed at Centralia. Nevertheless, the beneficial effect of ISCR treatment in reducing the concentration of chlorinated organics in the groundwater at Ramona must be balanced with the possibility of making the water source non-potable for a time.

\subsubsection{Reduction of Toxicity, Mobility, or Volume}

Under Alternative 4, carbon tetrachloride contamination above the RBSL and MCL values of $5 \mu \mathrm{g} / \mathrm{L}$ would be treated in situ, thereby decreasing contaminant toxicity, mobility, and volume at the former CCC/USDA facility. In addition, continued intrinsic remediation would result in a long-term decrease in the toxicity and volume of the contaminants present. Lateral mobility of contaminants is limited by the relatively low permeability of the impacted aquifer at the former CCC/USDA facility. However, water quality could be negatively affected.

\subsubsection{Short-Term Effectiveness}

During application of the ISCR treatment and well installation, site workers would be protected by adherence to Argonne's health and safety requirements and the provisions in the Master Work Plan (Argonne 2002) and the site-specific health and safety plan. No impacts to the local landowners are expected. Short-term risks to workers involved in monitoring and maintenance activities would be low. Although the ISCR component of the alternative offers the potential to bring the carbon tetrachloride concentration below the RBSL and MCL values of $5 \mu \mathrm{g} / \mathrm{L}$, the material could have a negative impact on groundwater quality in the short term. The negative effects would be expected to be of limited areal extent but for an unknown duration.

\subsubsection{Implementability}

Implementation of the ISCR treatment would be straightforward. Resources and wellestablished protocols (Argonne 2002) are readily available for installation of the needed monitoring wells. To date, investigators have been granted access to the property to collect soil 
samples and install and sample monitoring wells. Consequently, a request to install and sample additional monitoring wells is considered likely to be approved.

\subsubsection{Cost}

Costs for Alternative 4 were estimated for $5 \mathrm{yr}$ under the assumption that the remedy would be complete in that time. In contrast, costs for Alternatives 2 and 3 were estimated for $10 \mathrm{yr}$.

The estimated 5-yr cost for Alternative 4 is approximately $\$ 196,000$ in current-year dollars, with markups. Capital costs, estimated at $\$ 22,000$, include $\$ 17,000$ for the installation of two new ISCR performance monitoring wells and $\$ 5,000$ for professional labor management and in-well implementation of the ISCR treatment. Design costs are projected at $\$ 5,000$. Five-year monitoring costs are estimated at $\$ 136,000$ for (1) sampling of 4 existing wells in years $1-5$ (annually) and (2) treatment-specific sampling of the 2 newly installed wells and existing well MW04 (quarterly in year 1, twice annually in year 2, and annually in years 3-5). Included are costs for collecting and analyzing water samples, with the generation of annual reports to summarize the results. One 5-yr review would be performed, at a cost of $\$ 23,000$. If closeout documentation was required, the associated costs would be approximately $\$ 10,000$. The NPV cost of Alternative 4 is about $\$ 177,000$. 


\section{Comparative Analysis of Alternatives}

This section evaluates the relative performance of the four alternatives with respect to criteria 1-7, as described at the beginning of Section 5.

\subsection{Threshold Criteria}

\subsubsection{Overall Protection of Human Health and the Environment}

For the alternatives considered, under the realistic current-day scenario in which the present landowner does not have a water supply well in the impacted portion of the aquifer, Alternatives 1-4 are all protective. Under future use scenarios, however, Alternatives 1 and 2 place no constraint on the installation of a water supply well in the impacted portion of the aquifer. Nevertheless, contaminant levels are very low, and continued intrinsic remediation will result in a long-term decrease in the toxicity and volume of contaminants present and will ultimately be protective.

Alternative 3 provides protection of human health and the environment under a future use scenario, because the owner, by agreeing to a site-specific EUC, would preclude exposure to the impacted portion of the aquifer. In addition, for Alternative 4, ISCR treatment could decrease the carbon tetrachloride concentration. although water quality might be temporarily affected.

\subsubsection{Compliance with ARARs}

Concentrations of carbon tetrachloride at well MW07 currently exceed the RBSL and MCL values. With time, the concentration of carbon tetrachloride is expected to decrease and be in compliance. Alternatives 1, 2, and 3 would not actively reduce contaminant concentrations. Under Alternative 4, ISCR treatment could decrease the carbon tetrachloride concentration to the point of compliance with the RBSL and MCL values. However, Alternative 4 might adversely affect water quality to the point of non-compliance with secondary MCLs.

Location- and action-specific ARARs could be satisfied with all alternatives. 


\subsection{Primary Balancing Criteria}

\subsubsection{Long-Term Effectiveness and Permanence}

Alternatives 1, 2, and 3 would not involve active treatment to decrease the toxicity, mobility, or volume of contaminated groundwater at the site. Naturally occurring processes would reduce carbon tetrachloride concentrations in time. These alternatives would be protective of human health and the environment over the long term, in a realistic scenario in which impacted groundwater is not used as a water supply source. Because the only contamination present is located at depths of 40-60 ft BGL, there are no potential risks to ecological resources and members of the general public (such as trespassers) over the long term.

Alternative 3 offers long-term risk management in that EUCs would restrict well installations and preclude exposure to impacted groundwater until site closure is achieved. Alternative 4 would result in a permanent response action, because the ISCR treatment would directly and irreversibly address the carbon tetrachloride contamination in groundwater. However, Alternative 4 might adversely affect drinking water quality for an unknown duration.

\subsubsection{Reduction of Toxicity, Mobility, or Volume}

Although continued intrinsic remediation would result in a long-term decrease in the toxicity and volume of the contaminants present, Alternatives 1, 2, and 3 would not directly address the toxicity, mobility, or volume. The ISCR component of Alternative 4 would actively cause a decrease in the toxicity, mobility, and volume of contaminants but might negatively affect water quality.

\subsubsection{Short-Term Effectiveness}

Alternatives 1, 2, and 3 would not adversely affect the general public or the environment. During implementation of the ISCR treatment and monitoring well installation (Alternative 4) and during the monitoring activities associated with Alternatives 1, 2, and 3, site workers would be protected by adherence to Argonne's health and safety requirements and the provisions in the Master Work Plan (Argonne 2002) and the site-specific health and safety plan. The installation 
of the two new monitoring wells associated with Alternative 4 is not expected to negatively affect the owner of the former CCC/USDA property. No impacts to the other local landowners are expected. Short-term risks to workers involved in monitoring and maintenance activities would be low. Although the ISCR component of the alternative offers the potential to achieve carbon tetrachloride concentrations below the RBSL and MCL values of $5 \mu \mathrm{g} / \mathrm{L}$, the material could have a temporary negative effect on groundwater quality.

\subsubsection{Implementability}

The logistics of implementing each alternative would be straightforward. The present agricultural land use at the former CCC/USDA facility could continue under any alternative.

For Alternative 3, the EUC program has been shown to be mature and successful, and exposure to contaminated groundwater can be precluded by the proposed land use restrictions. The feasibility of Alternative 3 is dependent on the property owner's acceptance of these restrictions. For Alternative 4, ISCR treatment (by injection at Centralia) has been demonstrated to decrease carbon tetrachloride contamination (Argonne 2009). This technology, in the passivediffusion application proposed for Ramona, could be implemented with readily available resources.

\subsubsection{Cost}

Preliminary costs were estimated for each alternative to allow comparison of costs and effectiveness. The costs presented were estimated by using the RACER model (AECOM 2009), and certain assumptions were made regarding the design of the alternatives. Final costs will be developed during the design stage, after the preferred remedy has been selected.

Alternative 2 would be the least costly in the short term. For Alternative 4, additional costs above monitoring-related costs include the design, capital, and implementation costs associated with ISCR treatment; installation of two wells specifically for performance monitoring; and additional monitoring for the new wells. 


\subsection{Modifying Criteria (Stakeholder and State Acceptance)}

State acceptance will be reflected in KDHE comments on this CAS and the final corrective action selected. Stakeholder acceptance will be affected by the content of this CAS and by the corrective action approach taken for the Co-op to the north and west of the former CCC/USDA facility.

\subsection{Summary and Recommended Corrective Action}

The CCC/USDA recommends Alternative 3 for the former CCC/USDA facility at Ramona. Under the current scenario, with the former CCC/USDA property in agricultural production, Alternative 3 satisfies the threshold criterion for protecting human health and the environment (Section 6.1.1). Under a future use scenario, Alternative 3 offers the possibility of achieving compliance with regulatory requirements (Section 6.1.2) with time (due to intrinsic remediation) while precluding exposure to groundwater contaminated above primary MCLs. With regard to the balancing criteria (Section 6.2), Alternative 3 offers long-term effectiveness and permanence. Alternative 3 will result in a decrease in toxicity, mobility, and volume of contaminants at the site, since intrinsic remediation will result in a decrease in carbon tetrachloride concentrations over time. In general, the implementation of Alternative 3 would be straightforward.

For the balancing criterion of cost, Alternative 3 is the least costly alternative with a risk management component. Thus, Alternative 3 offers risk management and minimal cost. The comparison of restoration alternatives is summarized in Table 6.1. 
TABLE 6.1 Comparative analysis of aquifer restoration alternatives.

\begin{tabular}{|c|c|c|c|c|}
\hline $\begin{array}{l}\text { Evaluation } \\
\text { Criterion }\end{array}$ & $\begin{array}{l}\text { Alternative } 1- \\
\quad \text { No Action }\end{array}$ & $\begin{array}{l}\text { Alternative } 2- \\
\text { Monitoring }\end{array}$ & $\begin{array}{l}\text { Alternative } 3- \\
\text { Environmental Use Controls }\end{array}$ & $\begin{array}{l}\text { Alternative } 4- \\
\text { In Situ Chemical Reduction }\end{array}$ \\
\hline
\end{tabular}

Overall protection Protective under current use.

of human health

and the

environment

$100 \mathrm{ft}$ laterally or $40 \mathrm{ft}$

$100 \mathrm{ft}$ laterally or $40 \mathrm{ft}$
vertically of contaminated

groundwater. All nearby

residences are connected to

RWD \#1. Intrinsic remediation

would eventually bring $\mathrm{CCl}_{4}$

concentrations below

regulatory levels.

Compliance with federal and state ARARs

$\mathrm{CCl}_{4}$ would remain above $5 \mu \mathrm{g} / \mathrm{L}$ while intrinsic passive remediation occurred. No other ARARs apply.

Long-term

effectiveness and

permanence

Intrinsic remediation would eventually bring $\mathrm{CCl}_{4}$ concentrations permanently below regulatory levels.

\section{Reduction of} toxicity, mobility, and volume through treatmen

No treatment. Reductions in $\mathrm{CCl}_{4}$ would occur through

intrinsic remediation. Lateral mobility of $\mathrm{CCl}_{4}$ is limited by low permeability of the aquifer.

Short-term effectiveness

Protective under current use. No residences are within $100 \mathrm{ft}$ laterally or $40 \mathrm{ft}$ vertically of contaminated groundwater. All nearby residences are connected to RWD \#1. Intrinsic remediation would eventually bring $\mathrm{CCl}_{4}$ concentrations below regulatory levels.

$\mathrm{CCl}_{4}$ would remain above $5 \mu \mathrm{g} / \mathrm{L}$ while intrinsic passive remediation occurred. Would comply with all other ARARs.

Intrinsic remediation would eventually bring $\mathrm{CCl}_{4}$ concentrations permanently below regulatory levels.

No treatment. Reductions in $\mathrm{CCl}_{4}$ would occur through intrinsic remediation. Latera mobility of $\mathrm{CCl}_{4}$ is limited by low permeability of the aquifer.

No short-term effect on the quality of groundwater.
Protective under current use. No residences are within $100 \mathrm{ft}$ laterally or $40 \mathrm{ft}$ vertically of contaminated groundwater. All nearby residences are connected to RWD \#1. EUCs would decrease future potential for exposure by barring installation of water wells.

$\mathrm{CCl}_{4}$ would remain above $5 \mu \mathrm{g} / \mathrm{L}$ while intrinsic passive remediation occurred. Would comply with all other ARARs.

Intrinsic remediation would eventually bring $\mathrm{CCl}_{4}$ concentrations permanently below regulatory levels. EUCs would decrease future

potential for exposure.

No treatment. Reductions in $\mathrm{CCl}_{4}$ would occur through intrinsic remediation. Latera mobility of $\mathrm{CCl}_{4}$ is limited by low permeability of the aquifer

No short-term effect on the quality of groundwater.
Protective under current use. No residences are within $100 \mathrm{ft}$ laterally or $40 \mathrm{ft}$ vertically of contaminated groundwater. All nearby residences are connected to RWD \#1. Active ISCR treatment in well MW07 would reduce the $\mathrm{CCl}_{4}$ concentration, though it could compromise water quality in the aquifer for a time. Intrinsic remediation would also aid in bringing down $\mathrm{CCl}_{4}$ concentrations.

All ARARs would be met. Active ISCR treatment would be expected to bring $\mathrm{CCl}_{4}$ concentration below $5 \mu \mathrm{g} / \mathrm{L}$.

Active ISCR treatment would be expected to bring $\mathrm{CCl}_{4}$ concentration below $5 \mu \mathrm{g} / \mathrm{L}$ more rapidly than with intrinsic remediation alone.

In situ treatment would actively reduce contaminant toxicity, mobility, and volume. Lateral mobility is already limited by low permeability of the aquifer.

Active ISCR treatment in well MW07 would reduce the $\mathrm{CCl}_{4}$ concentration in the short term. The treatment could negatively affect water quality in the aquifer for a time.
No short-term effect on the quality of groundwater. 


\begin{tabular}{|c|c|c|c|c|}
\hline $\begin{array}{l}\text { Evaluation } \\
\text { Criterion }\end{array}$ & $\begin{array}{l}\text { Alternative } 1- \\
\quad \text { No Action }\end{array}$ & $\begin{array}{l}\text { Alternative } 2- \\
\quad \text { Monitoring }\end{array}$ & $\begin{array}{l}\text { Alternative } 3- \\
\text { Environmental Use Controls }\end{array}$ & $\begin{array}{l}\text { Alternative } 4- \\
\text { In Situ Chemical Reduction }\end{array}$ \\
\hline Implementability & No active measures taken. & Readily implementable. & $\begin{array}{l}\text { Readily implementable. } \\
\text { Feasibility of EUC depends on } \\
\text { owner cooperation. }\end{array}$ & $\begin{array}{l}\text { Could be accomplished by using } \\
\text { standard, readily available techniques. }\end{array}$ \\
\hline $\begin{array}{l}\text { Estimated costs in } \\
\text { the period } \\
\text { indicated in } \\
\text { current-year } \\
\text { dollars }\end{array}$ & None & $\$ 142,000$ in $10 \mathrm{yr}$ & $\$ 152,000$ in $10 \mathrm{yr}$ & $\$ 196,000$ in $5 \mathrm{yr}$ \\
\hline $\begin{array}{l}\text { Estimated costs in } \\
\text { NPV }\end{array}$ & None & $\$ 116,000$ & $\$ 126,000$ & $\$ 177,000$ \\
\hline
\end{tabular}




\section{Contingency Plan}

The CCC/USDA recommends Alternative 3 for the former CCC/USDA facility at Ramona (Section 6.4). At the direction of the KDHE (2011), the CCC/USDA defines the following contingency:

- If an evaluation of monitoring results indicates that contaminant concentrations in groundwater are not decreasing, the CCC/USDA will review the current site conditions and historical data to determine the most appropriate approach for addressing the contamination, including in situ treatment, pump and treat, and other currently available technologies. 


\section{References}

AECOM, 2009, Remedial Action Cost Engineering and Requirements System, AECOM Technology Corporation, Los Angeles, California.

Adventus, 2008, A-SOX TM The Easiest Deep Plume and Routine Deployment of Integrated Carbon, ZVI, and Nutrients, Adventus Group, Freeport, Illinois, February, accessed August 3, 2010 (http://www.adventusgroup.com/pdfs/a-sox/A-SOX\%20Flyer.pdf).

Anderson, M., and W. Woessner, 1992, Applied Groundwater Modeling - Simulation of Flow and Advective Transport, Academic Press, Inc., San Diego, California.

Aquaterra, 2009, Construction Documentation Report Source Area Pump and Treatment, Remedial System Installation, Frankfort PWS \#4 Site, Frankfort, Kansas, KDHE Project Code: C4-058-70122, Aquaterra Project Number: 3195.10, July.

Argonne, 2002, Final Master Work Plan: Environmental Investigations at Former CCC/USDA Facilities in Kansas, 2002 Revision, ANL/ER/TR-02/004, prepared for Commodity Credit Corporation, U.S. Department of Agriculture, Washington, D.C., by Argonne National Laboratory, Argonne, Illinois, December.

Argonne, 2005, Final Work Plan: Investigation of Potential Contamination at the Former USDA Facility in Ramona, Kansas, ANL/ER/TR-05/002, prepared for Commodity Credit Corporation, U.S. Department of Agriculture, Washington, D.C., by Argonne National Laboratory, Argonne, Illinois, November.

Argonne, 2007, Final Report: Results of the 2006 Investigation of Potential Contamination at the Former CCC/USDA Facility in Ramona, Kansas, ANL/EVS/AGEM/TR-07-10, prepared for Commodity Credit Corporation, U.S. Department of Agriculture, Washington, D.C., by Argonne National Laboratory, Argonne, Illinois, September.

Argonne, 2009, Progress Report and Technical Evaluation of the ISCR Pilot Test Conducted at the Former CCC/USDA Grain Storage Facility in Centralia, Kansas, ANL/EVS/AGEM/TR-0818, prepared for Commodity Credit Corporation, U.S. Department of Agriculture, Washington, D.C., by Argonne National Laboratory, Argonne, Illinois, January. 
EarthTech, 2005, Overview of the Remedial Action Cost Engineering Requirements (RACER) System, linked at http://www.afcee.af.mil/resources/restoration/racer/index.asp, accessed July 28 , 2010.

EPA, 1988, Guidance for Conducting Remedial Investigations and Feasibility Studies under CERCLA, Interim Final, EPA/540/G-89/004 (OSWER Directive 9355.3-01), U.S. Environmental Protection Agency, Washington, D.C., October (http://www.epa.gov/ superfund/ policy/remedy/pdfs/540g-89004-s.pdf).

EPA, 1990, National Oil and Hazardous Substances Contingency Plan: Final Rule (40 CFR Part 300, U.S. Environmental Protection Agency, Washington, D.C., (linked at http://www.epa.gov/OEM/lawsregs.htm\#ncp).

EPA, 1991, Risk Assessment Guidance for Superfund, Vol. 1, Human Health Evaluation Manual Part C, Risk Evaluation of Remedial Alternatives, EPA/540/R-92/004, Office of Emergency and Remedial Response, U.S. Environmental Protection Agency, Washington, D.C., December.

Fatherly, N., M. O'Neill, and A. Glemza, 2008, Formerly Used Sites Remedial Action Program (FUSRAP): W.R. Grace Feasibility Study (FS) Alternative Development Process Challenges and Successes, Waste Management Conference, Phoenix, Arizona, February 24-28.

GWP, 2010, A-SOX ${ }^{T M}$, Ground Water Products, Stone Mountain, Georgia, accessed August 3, 2010 (http://www.durhamgeo.com/Ground-Water/a-sox.htm).

Kansas, 2003, Kansas Statutes Annotated, Chapter 65. Public Health, Article 1. Secretary of Health and Environment, Activities, Statutes 65-1,221 to 65-1,235 (linked at http://www.kslegislature.org/legsrv-statutes/index.do).

Kansas, 2004, Kansas Administrative Regulations, 28-15a-61 Maximum Contaminant Levels for Organic Contaminants (http://www.kslegislature.org/ksadminregs/28-15a-61.html) and 28-15a62 Maximum Contaminant Levels for Inorganic Contaminants (http://www.kslegislature.org/ ksadminregs/28-15a-62.html). 
KDHE, 2001a, Scope of Work for a Corrective Action Study, Policy BER-RS-019, Remedial Section, Bureau of Environmental Remediation, Kansas Department of Health and Environment, Topeka, Kansas, March 29 (http://www.kdheks.gov/ber/policies/BER_RS_019_SOW.pdf).

KDHE, 2001b, Reclassification Plan, Policy BER-RS-024, Remedial Section, Bureau of Environmental Remediation, Kansas Department of Health and Environment, Topeka, Kansas, December 19 (http://www.kdheks.gov/ber/policies/BER_RS_033.pdf).

KDHE, 2002, Standards for Property Identification for Issuance of No Further Action Determinations, Policy BER-RS-VCP-003, Remedial Section, Bureau of Environmental Remediation, Kansas Department of Health and Environment, Topeka, Kansas, August 7 (http://www.kdheks.gov/ber/policies/BER_RS_VCP_003.pdf).

KDHE, 2005a, meeting of Kansas Department of Health and Environment, CCC/USDA, and Argonne representatives, Topeka, Kansas, September 8-9.

KDHE, 2005b, internal memorandum from C. Carey (Bureau of Environmental Remediation, Kansas Department of Health and Environment, Topeka, Kansas), through C. Jump and B. Wilson, to Ramona Site File (C5-057-70152), October 14.

KDHE, 2005c, Evaluating Future Land Use, Policy BER-RS-005, Remedial Section, Bureau of Environmental Remediation, Kansas Department of Health and Environment, Topeka, Kansas, December 19 (http://www.kdheks.gov/ber/policies/BER_RS_005.pdf).

KDHE, 2005d, Potential Applicable or Relevant and Appropriate Requirements (ARARs), Policy BER-RS-015, Remedial Section, Bureau of Environmental Remediation, Kansas Department of Health and Environment, Topeka, Kansas, August 9 (http://www.kdheks.gov/ber/policies/ BER_RS_015.pdf).

KDHE, 2005e, Considerations for Remedial Standards, Policy BER-RS-033, Remedial Section, Bureau of Environmental Remediation, Kansas Department of Health and Environment, Topeka, Kansas (http://www.kdheks.gov/ber/policies/BER_RS_024.pdf). 
KDHE, 2006, Supplemental Sampling Event Trip Report, City of Ramona Site, Ramona, Marion County, Kansas, Bureau of Environmental Remediation, Kansas Department of Health and Environment, Topeka, Kansas, July.

KDHE, 2007a, letter from C. Carey (Bureau of Environmental Remediation, Kansas Department of Health and Environment, Topeka, Kansas), to C. Roe (Commodity Credit Corporation, U.S. Department of Agriculture, Washington, D.C.), regarding draft report of the CCC/USDAArgonne 2006 investigation at Ramona, September 12.

KDHE, 2007b, Kansas Vapor Intrusion Guidance: Chemical Vapor Intrusion and Residential Indoor Air, Bureau of Environmental Remediation, Kansas Department of Health and Environment, Topeka, Kansas, June (http://www.kdheks.gov/ber/download/Ks_VI_ Guidance.pdf).

KDHE, 2007c, Risk Based Standards for Kansas: RSK Manual - 4th Version, Bureau of Environmental Remediation, Kansas Department of Health and Environment, Topeka, Kansas, June (www.kdheks.gov/remedial/rsk_manual_page.htm).

KDHE, 2007d, Environmental Use Control Program: Application to Participate, Version 7.0, Bureau of Environmental Remediation, Kansas Department of Health and Environment, Topeka, Kansas, February 20 (http://www.kdheks.gov/remedial/euc/download/eucapp.pdf).

KDHE, 2009a, Considerations for Groundwater Use and Applying RSK Standards to Contaminated Groundwater, Policy BER-RS-045, Remedial Section, Bureau of Environmental Remediation, Kansas Department of Health and Environment, Topeka, Kansas, June 19 (http://www.kdheks.gov/ber/policies/BER_RS_045.pdf).

KDHE, 2009b, Final Regulation: Article 73 - Environmental Use Controls Program, Kansas Department of Health and Environment, Topeka, Kansas, January 15 (http://www.kdheks.gov/ remedial/euc/download/euc_regs.pdf).

KDHE, 2010a, electronic mail message from C. Carey (Bureau of Environmental Remediation, Kansas Department of Health and Environment, Topeka, Kansas) to L.M. LaFreniere (Environmental Science Division, Argonne National Laboratory, Argonne, Illinois), March 4. 
KDHE, 2010b, electronic mail message from S. Aller (Bureau of Environmental Remediation, Kansas Department of Health and Environment, Topeka, Kansas) to L.M. LaFreniere (Environmental Science Division, Argonne National Laboratory, Argonne, Illinois), March 5.

KDHE, 2011, teleconference attended by C. Carey and M. Townsend (Bureau of Environmental Remediation, Kansas Department of Health and Environment, Topeka, Kansas) and C. Roe (Commodity Credit Corporation, U.S. Department of Agriculture, Washington, D.C.), February 8.

Marion County, 1994, Marion County, Kansas, Sanitation Code, prepared by D.L. Yearout, Planning Consultant, El Dorado, Kansas, for Marion County, Kansas, Board of Commissioners, Marion, Kansas, February (http://www.kdheks.gov/nps/lepp/county_codes/MarionCounty.pdf).

Pricewaterhouse Coopers, LLC, 2001, RACER Accreditation Recommendation, prepared for the Department of the Air Force, Civil Engineering Support Agency, Tyndall Air Force Base, July.

Richards, T., 2009, electronic mail message from Richards (Department of Planning and Zoning and Environmental Health, Marion County, Kansas, Marion, Kansas) to B. Nashold (Environmental Science Division, Argonne National Laboratory, Argonne, Illinois), October 27.

Servi-Tech, 2008, Investigative Work Plan: Ramona Groundwater Contamination Site, APA Facility, Servi-Tech, Inc., Dodge City, Kansas, February.

USGS, 1963, aerial photograph AYG-2DD-253, U.S. Geological Survey, Washington, D.C. August 2.

USGS, 2002, aerial photograph of Ramona, Kansas, U.S. Geological Survey, Washington, D.C. (as cited by KDHE [2006]).

Wick, P., 2010, telephone conversation between Wick (Mayor, City of Ramona, Kansas) and L. Martino (Argonne National Laboratory, Argonne, Illinois), January 11. 


\section{Appendix A:}

Potential Federal and State Applicable or Relevant and Appropriate Requirements and State Guidance Documents "To Be Considered" 
TABLE A.1 Potential federal applicable or relevant and appropriate requirements (ARARs) and guidance to be considered for former CCC/USDA facilities. $^{\mathrm{a}}$

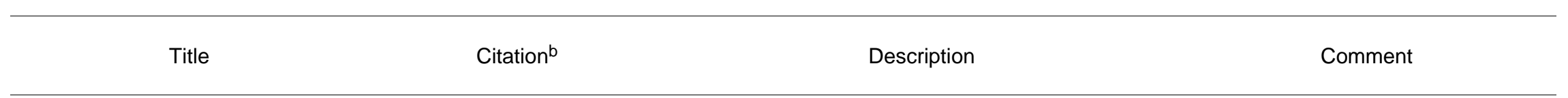

\section{Federal Laws and Regulations}

Comprehensive Environmental Response, Compensation, and Liability Act (CERCLA)

National Oil and Hazardous

Substances Pollution

Contingency Plan (NCP)

Safe Drinking Water Act (SDWA)

(Public Health Service Act)

National Primary Drinking Wate

Standards
42 USC 9601 et seq.

40 CFR Part 300

Provides the federal government's blueprint for responding to both oil spills and hazardous substance releases.

Off-Site Rule establishes procedures for planning and implementing off-site response actions (40 CFR 300.440).

42 USC 300(f) et seq.

40 CFR Part 141, Subparts B Establishes maximum contaminant levels (MCLs), and $\mathrm{G}$ which are health-based standards for public water systems. The MCL for carbon tetrachloride is

$5 \mu \mathrm{g} / \mathrm{L}$. The MCL for chloroform (total

trihalomethanes) is $80 \mu \mathrm{g} / \mathrm{L}$.
Applicable to releases into the environment of hazardous substances and pollutants or contaminants that may present an imminent and substantial danger to public health or the national welfare.

Applicable to response actions involving off-site transfers of hazardous substances, pollutants, or contaminants.

Applicable to organic groundwater contamination in a sole-source aquifer. 


\section{Safe Drinking Water Act (cont.)}

National Secondary Drinking

Water Regulations (NSDWRs)

Maximum Contaminant Level Goals (MCLGs)

Standards for Owners and Operators of Public Water

Supply Systems

Underground Injection Control Regulations

Sole-Source Aquifers
40 CFR Part 143

40 CFR Part 141, Subpart F

40 CFR Part 141

40 CFR Parts 144-148

40 CFR Part 149
Description

Comment

stablishes secondary maximum contaminant levels (SMCLs) for public water systems to protec the aesthetic quality of the water. The SMCLs are

not federally enforceable but are intended as guidelines for the states.

Establishes non-enforceable drinking water quality goals at levels of no known or anticipated adverse health effects, with an adequate margin of safety. The MCLG for carbon tetrachloride is zero.

Provides treatment requirements for public water supply systems (i.e., systems that serve at least 25 people or have at least 15 connections).

Provides for protection of underground sources of drinking water.

Prohibits activities, including drilling, in an area designated a sole-source aquifer without specia permission of the U.S. Environmental Protection Agency (EPA).
Applicable if groundwater is a source of drinking water and if the NSDWRs have been adopted as enforceable standards by the state.

May be relevant and appropriate if a more stringent standard is required to protect human health and the environment.

Relevant and appropriate in the establishment of cleanup goals for groundwater contamination.

Applicable if a response alternative involves underground injection.

Applicable if the aquifer in the area is a sole-source aquifer. 
Clean Water Act (Federal Water Pollution Control Act)

Ambient Water Quality Criteria

National Pollutant Discharge Elimination System (NPDES)
40 CFR Part 131

33 USC 1251 et seq.

40 CFR Parts 122-125
Section 304(a) of the Clean Water Act (CWA) [33 USC 1314(a)] requires the EPA to publish and periodically update ambient water quality criteria (AWQCs). These criteria must accurately reflect "the latest scientific knowledge ... on the kind and extent of all identifiable effects on health and welfare including, but not limited to, plankton, fish, shellfish, wildlife, plant life ... which may be expected from the presence of pollutants in any body of water. ..." Water quality criteria developed under Section 304(a) are based solely on data and scientific judgments on the relationship between pollutant concentrations and environmental and human health effects. These recommended criteria provide guidance for states and tribes in adopting water quality standards under Section 303(c) of the CWA [33 USC 1313(c)]

Establishes NPDES permit procedures, criteria, and standards governing the discharge of pollutants from any point source into waters of the United States [Sections 318, 402, and 405 of the CWA (33 USC 1328, 1342, 1345)]. Most storm water discharges require coverage by an NPDES permit.
Developed for some organic constituents in groundwater; may be relevant and appropriate.

Discharge limits will be established if effluent is discharged to a surface water body.

No permit is required for on-site response actions under CERCLA but the substantive requirements apply if a response alternative involves discharge into a creek or other surface water on-site. A permit is required if the discharge is to a creek or other surface water off-site. 


\section{Clean Water Act (cont.)}

Water Quality Standards

40 CFR Part 131

National Pretreatment

Standards

40 CFR Part 403

Dredge or Fill Requirements

40 CFR Parts 230-233

[40 CFR Part 6.302(a)]

Executive Order on Protection of Executive Order 11990 Wetlands

[40 CFR Part 6.302(a)]

Rivers and Harbors Act of 1899

33 USC 401 et seq.

Section 10 Permit

Executive Order on Floodplain

Management

33 CFR Parts 320-330

[40 CFR Part 6.302(a)]

Executive Order 11,988

[40 CFR Part 6.302(b)]
Description

Comment

Form the foundation of the water-quality-based pollution control program mandated by the CWA. These standards define the goals for a water body

by designating the water body's uses, setting criteria to protect those uses, and establishing provisions to protect water bodies from pollutants.

Provides general pretreatment standards and regulations for existing and new sources of pollution; establishes standards to control pollutants that pass through or interfere with treatment processes in publicly owned treatment works (POTWs) or that may contaminate sewage sludge.

Requires permits for discharge of dredged or fill material into navigable waters.

Requires federal agencies to avoid, to the extent possible, adverse impacts associated with the destruction or loss of wetlands and to avoid support of new construction in wetlands if a practicable alternative exists.

Requires a permit for structures for work in or affecting navigable waters.
Requires federal agencies to evaluate the potential effects of actions in a floodplain to avoid, to the extent possible, the adverse impacts associated with direct and indirect development of a floodplain.
Applicable to surface water discharges.

Applicable if a response alternative involves discharge to POTWs.

Applicable if a response alternative requires discharge of dredged or fill material into navigable waters.

Applicable if a response alternative has a negative effect on wetlands.

Applicable if a response alternative affects a navigable waterway.

Applicable if activities are located in a 100-yr floodplain. 


\section{Clean Air Act}

National Primary and Secondary Ambient Air Quality Standards

National Emissions Standards for Hazardous Air Pollutants (NESHAPs)

Solid Waste Disposal Act (as amended by the Resource Conservation and Recovery Act [RCRA])

\section{USC 7401 et seq.}

40 CFR Part 50

40 CFR Parts 61 and 63

40 USC 6901 et seq.
Establishes national primary and secondary

ambient air quality standards under Section 109 of the Clean Air Act (42 USC 7409) to protect public health and welfare.

Implements Section 112 of the Clean Air Act (42 USC 7412), which governs the federal control program for hazardous air pollutants (HAPs). Identifies emission standards for HAPs that originate from specific categories of sources, including site remediation. NESHAPs are technology based and are issued to limit the release of specified HAPs from specific industrial sectors. Federal Register notices published for carbon tetrachloride [50 FR 32621 (August 13, 1985)] and chloroform [50 FR 39626 (September 27, 1985)] included consideration of serious health effects, such as cancer, due to ambient exposures.
Comment

Applicable if contaminants are discharged to the air during treatment.

Applicable if the identified HAPs are emitted from a specific source category (for example, if on-site treatment units with emissions are part of response actions). 


\section{Solid Waste Disposal Act (cont.)}

Criteria for Classification of Solid 40 CFR Part 257 Waste Disposal Facilities and

Practices

Criteria for Municipal Solid

Waste Landfills

Identification and Listing of

Hazardous Wastes

Standards Applicable to

Generators of Hazardous Waste

Standards Applicable to

40 CFR Part 263

Transporters of Hazardous

Waste
Establishes classification criteria for sanitary

landfills and open dumps, which are prohibited

[Sections 4005 and 1008 of RCRA (42 USC 6945

and 6907)]. At a minimum, facilities meet the

sanitary landfill classification "only if there is no

reasonable probability of adverse effects on health

or the environment ..." [Section 4004(a) of RCRA (42 USC 6944(a))].

Provides for protection of surface water and groundwater at solid waste disposal facilities (40 CFR 257.3-3 and -4).

Establishes minimum national criteria for municipal solid waste landfill units.

Identifies solid wastes that are subject to regulation as hazardous wastes under 40 CFR Parts 124 , 262-265, 268, 270, and 271.

Establishes standards for generators of hazardous waste.

Establishes standards that apply to transporters of hazardous waste within the United States if the

transportation requires a manifest under 40 CFR Part 262
Applicable if a response alternative involves land disposal of solid waste.

Applicable if a response action includes provisions for an on-site landfill.

Applicable if municipal solid waste is placed in a municipal solid waste landfill.

Applicable if a material at the site is defined as a solid and hazardous waste; requires handling as a hazardous waste.

Applicable if hazardous wastes are generated as a result of on-site activities.

Applicable if a response alternative involves off-site transportation of hazardous wastes. 


\section{Solid Waste Disposal Act (cont.)}

Standards for Owners and Operators of Hazardous Waste Treatment, Storage, and

Disposal Facilities

Standards for Management of Specific Hazardous Wastes and

Specific Types of Hazardous

Waste Management Facilities

Land Disposal Restrictions

Hazardous Waste Permit

Program

Universal Wastes

Technical Standards and

Corrective Action Requirements

for Owners and Operators of

Underground Storage Tanks
40 CFR Part 280

40 CFR Part 264

40 CFR Part 266

40 CFR Part 268

40 CFR Part 270

40 CFR Part 273
Description

Comment

Establishes minimum national standards that define the acceptable management of hazardous wastes for owners and operators of facilities that treat, store, or dispose of hazardous waste.

Provides for groundwater protection standards, general monitoring requirements, corrective action requirements, and technical requirements.

Establishes requirements that apply to recyclable materials.

Identifies hazardous wastes that are restricted from land disposal; defines limited circumstances unde which an otherwise prohibited waste may continue to be land disposed.

Establishes provisions covering basic EPA permitting requirements.

Establishes requirements governing universal wastes (hazardous waste batteries, hazardous waste pesticides that are either recalled or collected in waste pesticide collection programs, hazardous waste thermostats, and hazardous waste lamps).

Establishes regulations related to underground storage tanks.
Applicable or relevant and appropriate if hazardous waste is disposed of on-site.

RCRA standards can be relevant and appropriate for groundwater at a site if an on-site landfill is constructed.

No substances are expected to be present at CCC/USDA sites in quantities to warrant recycling.

Applicable or relevant and appropriate if hazardous waste is disposed of on-site.

No permit is required for on-site CERCLA response actions.

Substantive requirements are addressed in 40 CFR Part 264.

Applicable if universal wastes are generated or managed on-site in the course of investigation or response operations.

Applicable if a response alternative involves use of underground storage tanks. 
Occupational Safety and Health Act (OSHA)

Occupational Safety and Health Standards

Noise Control Act of 1972

Hazardous Materials

Transportation Act

Hazardous Materials

Transportation Regulations
29 USC 651 et seq.

29 CFR Part 1910

42 USC Sect. 4901 et seq

49 USC 5101 et seq.

49 CFR Parts 106-180

Protects against the risks to life and property inherent in the transportation of hazardous material by listing the materials deemed hazardous and describing required labeling, placarding, and training. Hazardous materials are chemicals that the U.S. Department of Transportation has determined pose unreasonable risks to health, safety, and property during transportation activities.

Requires [Section 106 (16 USC 470(f))] federal agencies to consider the effects of any federally assisted undertaking (including those carried out with federal financial assistance and those requiring a federal permit, license, or approval) on any district, site, building, structure, or object that is listed in the National Register of Historic Places or eligible for such listing; requires agencies to give the Advisory Council on Historic Preservation a reasonable opportunity to comment on those undertakings.
Under 40 CFR Section 300.150 response actions under the NCP will comply with OSHA requirements for the safety and health of response action workers.

Applicable for activities such as drilling near a public access point.

Applicable if an alternative involves transportation of hazardous materials. Does not apply to on-site response operations. 
National Historic Preservation Act (cont.)

Protection of Historic Properties

36 CFR Parts 800

[40 CFR 6.301(b)]

Executive Order on Protection and Enhancement of Cultural Environments

\section{Executive Order on Preserve} America

Historic Sites, Buildings and Antiquities Act (Historic Sites Act) [40 CFR 6.301(a)]

Archaeological and Historic Preservation Act
Defines how federal agencies meet the statutory responsibilities.

Requires federal agencies to preserve, restore, and maintain the nation's historic and cultural environment in their activities.

Formulates policy to promote intergovernmental cooperation and partnerships for the preservation and use of historic properties.

Establishes a national policy to preserve historic sites and objects of national significance, including those located on refuges. Provides procedures for designation, acquisition, administration, and protection of such sites. Requires federal agencies to consider the existence and location of landmarks on the National Registry of Natural Landmarks and avoid undesirable impacts to such landmarks.

Carries out policy established by the Historic Sites Act. Establishes procedures for preservation of historical and archaeological data that might be lost or destroyed through alteration of terrain as a result of a federal construction project or a federally

licensed activity or program. Directs federal agencies to notify the Secretary of the Interior whenever they find that a federal or federally assisted, licensed, or permitted project may cause loss or destruction of significant scientific prehistoric, or archaeological data.
Applicable if a district, site, building, structure, or object listed on or eligible for the National Register is on or adjacent to the site.

Applicable if an entity on the National Register of National Landmarks is on or adjacent to the site.

Applicable if historical or archaeological data are on or adjacent to the site and if

construction projects or alteration of terrain at the site could destroy historical or archaeological materials. 
Antiquities Act

Title

Citation $^{b}$

Description

Comment

Authorizes the President to designate as national monuments objects or areas of historic or scientific interest on lands owned or controlled by the United States. Requires a permit for examination of ruins, excavation of archaeological sites, and the gathering of objects of antiquity on lands under the jurisdiction of the Secretaries of Interior, Agriculture and Army. Provides penalties for violations.

Preservation of American Antiquities

Archaeological Resources

Protection Act

Protection of Archaeological

Resources

American Indian Religious

Freedom Act
43 CFR Part 7 ,

36 CFR Part 296

[40 CFR 6.301(b)]

43 CFR 3

[40 CFR Sect. 6.301(b)]

Executive Order 11,593

16 USC 470aa et seq.

42 USC 1996 et seq.
Protects all historic and prehistoric sites on federal lands and prohibits excavation or destruction of such antiquities without the permission (Antiquities Permit) of the secretary of the department that has the jurisdiction over those lands; authorizes the President to declare areas of public lands as national monuments and to reserve or accept private lands for that purpose.

Supplements the provisions of the Antiquities Act of 1906. Establishes detailed requirements for issuance of permits for any excavation or for removal of archaeological resources from federal or Indian lands. Also establishes civil and criminal penalties for the unauthorized excavation, removal, or damage of such resources.

Establishes uniform definitions, standards, and procedures to be followed by all federal land managers in providing protection for archaeological resources located on public lands and Indian lands.

Protects and preserves the right of American ndians to have access to their sacred places directs federal agencies to consult with Indian religious practitioners if a place of religious importance to American Indians may be affected by an undertaking.
Applicable if site operations affect antiquities on federal lands.
Applicable if site operations affect archaeological resources on public or Indian lands.

Applicable if site operations affect access to sacred Indian sites. 
American Indian Religious

Freedom Act (cont.)

Executive Order on Indian Sacred Sites

Native American Grave Protection and Repatriation Ac

Native American Graves

Protection and Repatriation

Regulations
Executive Order 13,007

25 USC 3001 et seq.

43 CFR Part 10

16 USC 1531 et seq.
Requires agencies managing federal lands to accommodate access to and ceremonial use of Indian sacred sites by Indian religious practitioners and to avoid adversely affecting the physica integrity of such sacred sites; also requires agencies to develop procedures for reasonable notification of proposed actions.

Establishes the priority for ownership or control of Native American cultural items excavated or discovered on federal or tribal lands after 1990 and the procedures for repatriation of items in federal possession; allows the intentional removal or excavation of Native American cultural items from federal or tribal lands only with a permit or upon consultation with the appropriate tribe.

Develops a systematic process for determining the rights of linear descendants and Indian tribes to certain Native American human remains, funerary objects, sacred objects, or objects of cultural patrimony. Defines items included under the Native American Grave Protection and Repatriation Act.

Describes the consultation procedure applicable to intentional excavation or inadvertent discovery of remains or objects covered.

Provides for the conservation of threatened and endangered plants and animals and the habitats in which they are found.
Applicable if site operations affect access to sacred Indian sites.

Applicable if site operations involve excavation or discovery of Native American cultural items on federal or tribal lands. 
TABLE A.1 (cont.)

\begin{tabular}{ccc}
\hline Title & Citation & Description \\
\hline
\end{tabular}

Interagency Cooperation

50 CFR Part 402

[40 CFR 6.302(h)]

Migratory Bird Treaty Act

Migratory Bird Permits

Executive Order on

Responsibilities of Federal

Agencies to Protect Migratory

Birds

Bald and Golden Eagle Protection

Act

\section{Eagle Permits}

50 CFR Parts 10 and 22

Fish and Wildlife Conservation Act

16 USC 703 et seq.

50 CFR Parts 10 and 21

Executive Order 13,186
Requires action to conserve threatened and endangered species within critical habits upon which endangered species depend, including consultation and conferencing with the Department of the Interior (U.S. Fisheries and Wildlife

Service/U.S. National Marine Fisheries Service).

Requires a permit from the U.S. Fisheries and Wildlife Service for the taking of protected migratory birds.

Directs federal agencies taking actions having or likely to have a negative effect on migratory bird populations to work with the U.S. Fisheries and

Wildlife Service to develop an agreement to conserve those birds.

Requires a permit from the U.S. Fisheries and Wildlife Service to move nests because of construction or operation of project facilities.

Encourages states to develop conservation plans for nongame fish and wildlife of ecological,

educational, aesthetic, cultural, recreational, economic, or scientific value.
Applicable if threatened or endangered species or critical habitats are identified at the site.
Applicable if a response alternative will affect a migratory pathway. 
Fish and Wildlife Coordination Act 16 USC 661 et seq. [40 CFR 6.302(g)]

Wilderness Act

Wilderness Preservation and Management

Management of Designated

Wilderness Areas

National Wildlife Refuge System Administration Act

\section{Executive Order on Management Executive Order 12,996} and General Public Use of the

National Wildlife Refuge System

16 USC 1311 et seq.

50 CFR Part 35

43 CFR Part 6300

16 USC 668dd
Requires consultation with the U.S. Fish and Wildlife Service when a federal department or agency proposes, authorizes, permits, or licenses any modification of any stream or other water body. Requires adequate provision for protection of fish and wildlife resources.

Directs preservation of a national network of lands and waters for the conservation and management of fish, wildlife, and plant resources for the benefit of present and future generations. Recognizes compatible uses, while ensuring maintenance of biological integrity and environmental health.

States that a federal agency may not assist, through grant, loan, license, or otherwise, the construction of a water resources project that would have a direct and adverse effect on the values for which a river in the National Wild and Scenic Rivers System or a study river on the National Rivers Inventory was established (as determined by the Secretary of the Interior or the Secretary of Agriculture, for rivers under their respective jurisdictions).
Applicable if a response alternative will cause damage to or loss of wildlife by modifying a stream or body of water.

Comment

Applicable if a wilderness area exists on-site or adjacent to the site.

Applicable if a wildlife refuge area exists on-site or adjacent to the site. 
Wild and Scenic Rivers Act

(cont.)

Wild and Scenic Rivers

36 CFR Part 297

(40 CFR 6.302(e))

Federal Guidance "To be Considered"

Draft Guidance for Evaluating

the Vapor Intrusion to Indoor Air

Pathway from Groundwater and

Soils (Subsurface Vapor

Intrusion)
67 FR 71169 (Nov. 29, 2002)

The draft guidance is intended to be a screening tool to aid users in determining whether a vapor

intrusion pathway is complete and, if so, whether the complete pathway poses an unacceptable risk to human health at cleanup sites. With a complete

pathway, humans are exposed to vapors originating from site contamination. The draft guidance begins with simple and, in general, reasonably

conservative screening approaches and gradually

progresses toward a more complex assessment

involving increasingly greater use of site-specific

data. For sites determined to have an incomplete

vapor intrusion pathway, further consideration of the

current site situation generally should not be

needed. For sites determined to have a complete

pathway, guidance is provided to evaluate whether

the pathway does or does not pose a potential

significant risk to human health. The draft guidance

is not intended to provide recommendations to

delineate the extent of risk or eliminate the risk.
Applicable to on-site water resource projects located within, above, below, or outside a wild and scenic river or study river.

Suggested for use at National Priorities List and Superfund

Alternative Sites.

a Abbreviations for citations:

CFR, Code of Federal Regulations

FR, Federal Register

USC, United States Code

Sect., Section 
TABLE A.2 Potential state applicable or relevant and appropriate requirements (ARARs) for former CCC/USDA facilities in Kansas. ${ }^{a}$

Title Citation ${ }^{b}$ Description

Kansas Air Quality Control Act; Kansas Air Quality Regulations
KSA, Chapter 65, Article 30; KAR, Title 28, Article 19
Requires permitting and preconstruction notice for air contaminant sources. Provides for reporting and inspections. Establishes state emission standards for listed hazardous air pollutants (HAPs) and state air quality standards to protect the public health.

Provides emission standards for HAPs (KAR 2819-200 et seq.). HAPs include carbon tetrachloride and chloroform [KAR 28-19-201(a)]. Emission above a certain threshold requires an annual emissions fee (e.g., 10 tons/yr of a single HAP and 25 tons/yr of any combination of HAPs) (KAR 2819-202).

Emissions above certain threshold amounts require a construction permit (e.g., 25 tons/yr of particulate matter [PM], 15 tons/yr of PM 10, 100 tons/yr of carbon monoxide, 40 tons/yr of volatile organic compounds [VOCs]) or a preconstruction approval (e.g., $5 \mathrm{lb} / \mathrm{hr}$ of PM, $2 \mathrm{lb} / \mathrm{hr}$ of PM 10, $50 \mathrm{lb}$ per 24-hr period of carbon monoxide, $50 \mathrm{lb}$ per 24-hr period of VOCs (either $15 \mathrm{lb}$ per 24-hr period or $3 \mathrm{lb} / \mathrm{hr}$ in a nonattainment area) (KAR 28-19-300).

Requires operating permits for certain stationary sources (28-19-500 et seq.)

Prohibits open burning (28-19-645 et seq.)

Establishes new source performance standards for municipal solid waste landfills, including reporting, calculating nonmethane organic compound

emissions, installing collection and control systems (28-19-720 et seq.).

Establishes emission standards for major source HAPs (28-19-750 et seq.).
Applicable if any listed pollutants are discharged to the air during investigation or response through air stripping, thermal destruction, handling of contaminated soil, gaseous waste treatment, aeration, or disposal in a municipal solid

waste landfill. 
TABLE A.2 (Cont.)

Title Citation $\quad$ Description

Underground Storage, Disposal

Wells and Surface Ponds

Drinking Water Regulations

Water Pollution Control

Regulations
KSA, Chapter 65, Article 1;

$\mathrm{KAR}$, Title 28, Article 13

KSA, Chapter 65, Article 33; KAR, Title 28, Article 15 KAR, Title 28, Article 16
Regulates the construction and use of

underground storage reservoirs, disposal wells, and surface ponds for the confinement, storage, and disposal of industrial fluids. Establishes approval and permitting requirements.

Establishes maximum contaminant levels (MCLs) pertaining to public water supplies. The MCLs for carbon tetrachloride, total trihalomethanes (including chloroform), nitrate, and nitrite are $0.005 \mathrm{mg} / \mathrm{L}, 0.1 \mathrm{mg} / \mathrm{L}, 10 \mathrm{mg} / \mathrm{L}$, and $1 \mathrm{mg} / \mathrm{L}$, respectively (KAR 28-15a-61 and 28-15a-62).

Provides for the maintenance and protection of public health and welfare and the use of surface water for aquatic life; for agricultural, domestic, and industrial water supply; and for recreation. Controls surface water use designation. Establishes surface water quality standards (KAR 28-16-28 et seq.).

MCL defined as "any of the enforceable standards for finished drinking water promulgated by the U.S Environmental Protection Agency [KAR 28-16$28 \mathrm{~b}(\mathrm{hh})]$.

When the KDHE finds that the criteria listed are underprotective or overprotective for a given surface water segment, the KDHE may, in accordance with KAR 28-16-28f(f), make appropriate site-specific determinations. (KAR 28$16-28 e(a)$. Surface water must be free from the harmful effects of substances that produce any public health hazard; hazardous substances must not occur in surface water at concentrations that jeopardize public health and other protected life [KAR 28-16-28e(b)].
Applicable if a response alternative involves the need for underground storage reservoirs, disposal wells, or surface ponds.

Applicable if waste derived from investigation or response enters public water systems. Not applicable to investigative wells, as such, that are not used for drinking water supply; however, relevant for establishing sampling and analysis parameters and analytical detection limits during investigation activities.

Applicable if contaminated effluent from investigative or response operations were discharged into surface water; also might be applicable to alluvial aquifers demonstrated to be hydraulically connected to surface water bodies. 


\begin{tabular}{ccc}
\hline Title & Citation & Description \\
\hline
\end{tabular}

Water Pollution Control

Regulations (cont.)

Provides numeric criteria by use category for different parameters (KAR 28-16-28e(d)). For chloroform the values are $28,900 \mu \mathrm{g} / \mathrm{L}$ for aquatic life-acute, 1,240 $\mu \mathrm{g} / \mathrm{L}$ for aquatic life-chronic, $470 \mu \mathrm{g} / \mathrm{L}$ for public health-food procurement, and $100 \mu \mathrm{g} / \mathrm{L}$ for public health-domestic water supply. (No values are specified for agriculture-livestock and agriculture-irrigation.) For carbon tetrachloride the value is $35,200 \mu \mathrm{g} / \mathrm{L}$ for aquatic life-acute $6.94 \mu \mathrm{g} / \mathrm{L}$ for public health-food procurement, and $5 \mu \mathrm{g} / \mathrm{L}$ for public health-domestic water supply. (No values are specified for aquatic life-chronic, agriculture-livestock, and agriculture-irrigation.)

Establishes procedures relating to the discharge of wastewaters under the NPDES program (KAR 2816-57 et seq.). National effluent standards are adopted by reference.

Provides for the establishment and administration of critical water quality management areas (KAR 28-16-69 et seq.).

Establishes limitations on the types of wastes that can be discharged to publicly owned treatment works (POTWs) and governs pollutants from nondomestic sources that are subject to one or more pretreatment standards and that are indirectly discharged, or otherwise introduced by any means, into POTWs (KAR 28-16-83 et seq.).

Groundwater Management Districts
KSA, Chapter 82a, Article 10
Establishes requirements for the creation of special districts for the proper management of the groundwater resources of the state; for the conservation of groundwater resources
Applicable if investigation or response operations involve discharge into "waters of the state."

Applicable if contaminants resulting from a response are discharged into a designated critical water quality management area.

Applicable if investigation or response alternatives involve discharge of contaminated groundwater to POTWs.

Applicable if investigation or response alternatives occur within one of the special districts created for the management of groundwater. 


\begin{tabular}{ccc}
\hline Title & Citation & Description \\
\hline
\end{tabular}

Kansas Water Well Contractor's License Regulations; Water Well Construction and Abandonment Regulations

Underground Injection Control Regulations

Solid Waste Regulations
KSA, Chapter 82a, Article 12; KAR, Title 28, Article 30

KSA, Chapter 65, Article 1: KAR, Title 28, Article 46

KSA, Chapter 65, Article 34; KAR, Title 28, Article 29
Establishes requirements for licensing of well drillers and standards for construction, operation, and abandonment of wells (KAR 28-30-3 et seq.)

Governs discharges into underground injection wells (KAR 28-46-1 et seq.). In general, federal Safe Drinking Water Act regulations are adopted by reference.

Establishes standards for management activities and facilities relative to solid wastes (KAR 28-29-1 et seq.).

Establishes location restrictions, design standards, operating standards, groundwater monitoring corrective action, and financial assurance for closure and postclosure, for municipal solid waste landfill units (KAR 28-29-100 et seq.). Liner standards for new municipal solid waste landfills must be designed in accordance with KAR 28-19104(e)(1)(A)or(B). Alternative designs must demonstrate that a carbon tetrachloride

concentration of $0.005 \mathrm{mg} / \mathrm{L}$ will not be exceeded in the uppermost aquifer at an agreed-upon poin of compliance [KAR 28-29-104(e)(1)(B)]. (Small units may request exemption and function under modified monitoring, design and operating requirements (KAR 28-29-103). Requires detection and assessment monitoring for carbon

tetrachloride and chloroform (KAR 28-29-113).
Applicable if investigation or response involves drilling and installing wells that intercept the water table.

Applicable if investigative or response wastes are introduced into wells for discharge or disposal.

\section{Applicable if nonhazardous}

materials discarded as a result of an investigation or response are landfilled on-site.

Applicable if a municipal solid waste landfill is used. 


Title Citation $\quad$ Description

Hazardous Waste Management Standards and Regulations
KSA, Chapter 65, Article 34; KAR, Title 28, Article 31
Requires generators of solid waste to make a hazardous waste determination. For a waste that is not excluded from hazardous waste regulations and not listed as a hazardous waste, the determination is generally made through testing by a laboratory certified for such analyses by the KDHE [KAR 28-31-4(b)].

Establishes standards for hazardous waste generators and transporters and for facilities that treat, store, or dispose of hazardous waste (KAR 28-31-4 et seq.). Storage by certain hazardous waste generators for more than 90 days or treatment or disposal of hazardous waste requires a permit [KAR 28-31-4(g)]. Adopts by reference federal land disposal restrictions (KAR 28-31-14).

Adopts by reference federal regulations governing universal wastes (KAR 28-31-15).

Establishes standards for the registration and permitting of nonexempt aboveground tanks used to store a regulated substance (KAR 28-44-29).
Applicable if investigation or

response operations generate solid wastes.

Applicable to response-generated wastes that are determined to be hazardous and that are managed on-site through treatment, storage, and disposal or are transported.

Transportation requirements do not include a manifesting requirement

for samples sent for characterization or treatability studies.

Applicable if universal wastes are generated or managed on-site in the course of an investigation or response operation.

Applicable if a response alternative involves use of storage tanks (to contain an accumulation of

regulated substances), associated piping and ancillary equipment, and the containment system. 


\begin{tabular}{|c|c|c|c|}
\hline Title & Citation $\mathrm{b}$ & Description & Comment \\
\hline $\begin{array}{l}\text { Kansas Nongame and } \\
\text { Endangered Species } \\
\text { Conservation Act; Kansas } \\
\text { Nongame and Endangered } \\
\text { Species Conservation } \\
\text { Regulations }\end{array}$ & $\begin{array}{l}\text { KSA, Chapter 32, Article 9; } \\
\text { KAR, Title 115, Article } 15\end{array}$ & $\begin{array}{l}\text { Designates endangered and threatened species, } \\
\text { as well as nongame species in need of } \\
\text { conservation. Requires consultation with the } \\
\text { Kansas Department of Wildlife and Parks } \\
\text { pertaining to actions that might affect listed species } \\
\text { and their critical habitats. Projects that affect listed } \\
\text { species or their habitat and that are publicly } \\
\text { funded, state or federally assisted, or require a } \\
\text { permit from another state or federal agency require } \\
\text { review and action permits (KSA 32-957 through - } \\
963,32-1009 \text { through } 32-1012, \& 32-1033 ; \text { KAR } \\
115-15-1,-2,-3 \text {, and -4). }\end{array}$ & $\begin{array}{l}\text { Applicable if threatened or } \\
\text { endangered species are identified at } \\
\text { or near the site. }\end{array}$ \\
\hline Kansas Levee Law & $\begin{array}{l}\text { KSA, Chapter 24, Article 1; } \\
\text { KAR, Title 5, Article } 45\end{array}$ & $\begin{array}{l}\text { Requires prior approval of chief engineer before } \\
\text { construction of floodplain fills and levees } \\
\text { (KSA 24-126). "Floodplain fill" means material, } \\
\text { usually soil, rock, or rubble, placed in a floodplain } \\
\text { to an average height of more than } 1 \mathrm{ft} \text { above the } \\
\text { existing ground, which has the effect of diverting, } \\
\text { restricting, or raising the level of floodwaters on a } \\
\text { stream (KAR 5-45-1). }\end{array}$ & $\begin{array}{l}\text { Applicable if site activities involve } \\
\text { construction of floodplain fills. }\end{array}$ \\
\hline Kansas Historic Preservation Act & $\begin{array}{l}\text { KSA, Chapter } 75 \text {, Article } 27 \text {; } \\
\text { KAR, Title } 118 \text {, Article } 3\end{array}$ & $\begin{array}{l}\text { Provides for protection and preservation of sites } \\
\text { and buildings listed on state or federal historic } \\
\text { registries (KSA 75-2715 through 75-2726; KAR } \\
\text { 118-3-1 through 118-3-16). }\end{array}$ & $\begin{array}{l}\text { Applicable if the investigation or } \\
\text { response site is a listed state or } \\
\text { federal historic site or is adjacent to } \\
\text { such a site and if activities requiring } \\
\text { permitting are initiated at the site. }\end{array}$ \\
\hline
\end{tabular}

\section{dangered Species \\ Nongame and Endangered \\ Species Conservation \\ Regulations}

KSA, Chapter 24, Article 1

KAR, Title 5, Article 45

KSA, Chapter 75, Article 27; registries (KSA 75-2715 through 75-2726; KAR species are identified at as well as nongame species in need of

Kansas Department of Wildlife and Parks

dheir critical habitats. Projects that affect listed

963, 32-1009 through 32-1012, \& 32-1033; KAR

Requires prior approval of chief engineer before of floodplain fills and levees

(KSA 24-126). "Floodplain fill" means material,

usually soil, rock, or rubble, placed in a floodplain

restricting, or raising the level of floodwaters on a stream (KAR 5-45-1).

permitting are initiated at the site. 
TABLE A.2 (Cont.)

\begin{tabular}{|c|c|c|c|}
\hline Title & Citation ${ }^{b}$ & Description & Comment \\
\hline $\begin{array}{l}\text { Kansas Unmarked Burial Sites } \\
\text { Preservation Act }\end{array}$ & $\begin{array}{l}\text { KSA Chapter } 75 \text {, Article 27; } \\
\text { KAR Title } 126 \text {, Article } 1\end{array}$ & $\begin{array}{l}\text { Establishes Burial Sites Preservation Board; } \\
\text { prohibits unauthorized disturbance; requires } \\
\text { permits for excavation of any unmarked burial site, } \\
\text { registered or unregistered (KSA 75-2741 through } \\
\text { 75-2754; KAR 126-1-1 through 126-1-2). }\end{array}$ & $\begin{array}{l}\text { Applicable if investigation or } \\
\text { remediation activities encounter a } \\
\text { burial site. }\end{array}$ \\
\hline $\begin{array}{l}\text { Agricultural and Specialty } \\
\text { Remediation Act }\end{array}$ & $\begin{array}{l}\text { KSA Chapter } 2 \text {, Article } 37 \\
\text { KAR Title } 124 \text {, Article } 1\end{array}$ & $\begin{array}{l}\text { Provides for the reimbursement of corrective action } \\
\text { costs resulting from an incident involving a rupture, } \\
\text { leak, spill, emission, discharge, disposal, or any } \\
\text { other event that releases an agricultural or } \\
\text { specialty chemical accidentally or otherwise into } \\
\text { the environment. Releases resulting from the } \\
\text { normal use of a product or practice in accordance } \\
\text { with the law are not covered. }\end{array}$ & $\begin{array}{l}\text { Applicable if remediation activities } \\
\text { involve the release of an agricultural } \\
\text { or specialty chemical. Costs to the } \\
\text { federal government are considered } \\
\text { ineligible. }\end{array}$ \\
\hline
\end{tabular}

a Abbreviations for citations:

KSA, Kansas Statutes Annotated

KAR, Kansas Administrative Regulations 
TABLE A.3 State guidance documents "to be considered" for former CCC/USDA facilities in Kansas.

\begin{tabular}{|c|c|c|}
\hline Number & Title & Date \\
\hline BER-032 & Guidelines for Obtaining an Alternative Public Drinking Water Source (formerly BER-RS-032) & 2005 \\
\hline (no BER-R-002 number provided) & Kansas Vapor Intrusion Guidance Chemical Vapor Intrusion and Residential Indoor Air & 2007 \\
\hline BER-RS-002 & Public Information Program & 1993 \\
\hline BER-RS-003 & Characterization and Management of Contaminated Soil Cuttings & Revised 1996 \\
\hline BER-RS-004 & Cost Recovery of EPA's Past Costs & Revised 2005 \\
\hline BER-RS-005 & Evaluating Future Land Use & Revised 2005 \\
\hline BER-RS-006 & Final Guidance for Verification Sampling of Non-Hazardous Industrial Wastewater Ponds & Revised 1996 \\
\hline BER-RS-007 & Minimum Standards for Model Use & Revised 2005 \\
\hline BER-RS-009 & Development of Draft CADs & Revised 2005 \\
\hline BER-RS-011 & Utilization of Funding Through the State Water Plan & Revised 2001 \\
\hline BER-RS-012 & Recommended Remedial Levels for Nitrate and Ammonia in Soils & Revised 2002 \\
\hline BER-RS-013A & Investigation and Remediation of Salt (Chloride)-Impacted Soil and Groundwater & Revised 2005 \\
\hline BER-RS-015 & Potential Applicable or Relevant and Appropriate Requirements ARARs & Revised 2005 \\
\hline BER-RS-017 & Scope of Work (SOW) for a Preliminary Investigation & Revised 2005 \\
\hline BER-RS-018 & Scope of Work (SOW) for a Comprehensive Investigation & Revised 2005 \\
\hline BER-RS-019 & Scope of Work (SOW) for a Corrective Action Study & Revised 3-29-01 \\
\hline BER-RS-020 & Scope of Work (SOW) for a Comprehensive Investigation (CI)/Corrective Action Study (CAS) & Revised 2005 \\
\hline BER-RS-023 & Scope of Work (SOW) for a Corrective Action Plan (CAP)/Corrective Action (CA) & Revised 2005 \\
\hline BER-RS-024 & Reclassification Plan & Revised 2001 \\
\hline BER-RS-025 & Scope of Work (SOW) for a Remedial Investigation (RI)/Feasibility Study (FS) & Revised 2005 \\
\hline BER-RS-026 & Scope of Work (SOW) for a Remedial Design (RD)/Remedial Action (RA) & Revised 2005 \\
\hline BER-RS-027 & Reimbursement of Costs for use of KDHE Direct-Push and Mobile Laboratory & Revised 2005 \\
\hline BER-RS-028 & Consideration for Hydraulic Containment & Revised 2005 \\
\hline BER-RS-031 & Removal Site Evaluation (RSE)/Removal Action Design (RAD)/Removal Action (RA) & Revised 1996 \\
\hline BER-RS-032 & Guidelines for Obtaining an Alternative Public Drinking Water Source (changed to BER-032, 2005) & 1995 \\
\hline BER-RS-033 & Considerations for Remedial Standards & Revised 2005 \\
\hline BER-RS-034 & Mercury Contamination Characterization at Gas Pipeline Sites & Revised 2005 \\
\hline BER-RS-035 & Mercury Contamination Remediation at Gas Pipeline Sites & Revised 2005 \\
\hline BER-RS-036 & Scope of Work for Site Monitoring & Revised 2005 \\
\hline BER-RS-037 & State Cooperative Program & 2005 \\
\hline BER-RS-039 & Scope of Work for a Qualitative Risk Assessment & Revised 2005 \\
\hline BER-RS-041 & Clean-up Levels for Total Petroleum Hydrocarbons & 2000 \\
\hline BER-RS-041 & Addendum & 2001 \\
\hline BER-RS-042 & Monitored Natural Attenuation & Revised 2005 \\
\hline BER-RS-045 & Considerations for Groundwater Use and Applying RSK Standards to Contaminated Groundwater & 2004 \\
\hline BER-RS-046 & Filtering Water Samples Collected for Metal Analysis & 2006 \\
\hline BER-RS-047 & Scope of Work (SOW) For a Nitrate Presumptive Remedy & 2003 \\
\hline BER-RS-048 & Consideration and Selection of Borrow Sites & 2007 \\
\hline BER-RS-049 & Cost Recovery Guidance for KDHE/BER Activities at Sites Determined to have Responsible Parties & 2007 \\
\hline BER-RS-050 & $\begin{array}{l}\text { Remediating Soil From Agricultural Chemical Incidents by Excavation \& Land Applications Interim } \\
\text { Measures }\end{array}$ & 2007 \\
\hline
\end{tabular}


BER-RS-VCP-001 BER-RS-VCP-002

BER-RS-VCP-003

BER-RS-VCP-004

BER-RS-BF-001

BER-ARS-044

BER-ARS-045

\section{VCPRP Initial Deposits For Grouped Properties}

Eligibility Determinations Concerning Public or Private Drinking Water Well Situations

Standards for Property Identification For Issuance of NFA Determinations

Transfer of Contaminated Sites From the State Cooperative Program to the Voluntary Cleanup and

Property Redevelopment Program

Property Eligibility for Assessments Conducted by the Brownfields Program

Natural Resource Damage Assessments

Sediment Policy

Kansas Petroleum Storage Tank Release Trust Fund Policy and Procedures Manua

Kansas Storage Tank Program Aboveground Storage Tank Overview

Updated Policy and Procedures Manual for the Preventative/UST Unit Storage Tank Section
2004

2000

2002

2003

2004

2002

2004

$-$ 
Appendix B:

Basis for Cost Estimation for Ramona CAS 


\section{Appendix B:}

\section{Basis for Cost Estimation for Ramona CAS}

The costs presented here were estimated by using the Remedial Action Cost Engineering and Requirements (RACER) model (AECOM 2009), a tool for accurate cost estimation for all phases of remediation. RACER is a Windows-based, verified, validated, accredited cost estimating tool designed to provide a total cost to investigate and clean up a site. RACER has been accredited by Pricewaterhouse Coopers, LLP (2001), for the following intended use:

To provide an automated, consistent and repeatable method to estimate and document the program cost for the environmental cleanup of contaminated sites and to provide a reasonable cost estimate for program funding purposes consistent with the information available at the time of the estimate preparation.

The model was developed specifically for estimating costs associated with investigating and cleaning up contaminated sites, costs also known as "environmental liabilities." The system can be used for the early order-of-magnitude estimating stage of a project or can provide a more detailed cost estimate. The RACER model has been employed by hundreds of users, including the U.S. Department of Defense, Department of Energy, Department of the Interior and Environmental Protection Agency; consultants; and state regulatory agencies. The accuracy of the RACER system has been determined to be within $10 \%$ of completed projects costs.

The RACER model is a parametric cost estimating system with two components that work in tandem: (1) an expert system that can estimate the amount and nature of work to be performed to address environmental liabilities and (2) a detailed database of unit prices. The user can enter site-specific information that customizes generic engineering solutions and results in the calculation of the quantities of labor, equipment, and materials necessary to complete the project. The work quantities and the database of unit prices are then used to calculate costs. The RACER system is structured to calculate costs for the following project life cycle phases: prestudy, study (site investigation study or corrective action study), design, removal/interim action, corrective action, long-term monitoring, and site closeout.

The RACER system is used to calculate environmental liabilities in connection with mergers, acquisitions, divestitures, and legal disputes, but one of its primary uses is for the 
development of cost estimates for feasibility studies and RCRA Corrective Measures Studies, corollaries to the KDHE CAS (EarthTech 2005). Users can select from among many cleanup technologies (32 for treatment and 13 for removal), as well as multiple long-term monitoring technologies, to develop a cost estimate for site remediation. For example, the U.S. Army Corps of Engineers-Baltimore District used RACER to develop costs for 6 alternatives in a feasibility study for the cleanup of a former Atomic Energy Commission site (Fatherly 2008).

Additional information is linked at the following location:

http://www.afcee.af.mil/resources/restoration/racer/index.asp

The cost estimate for Alternative 4 is for $5 \mathrm{yr}$, and the estimates for Alternatives 2 and 3 are for $10 \mathrm{yr}$. Costs are for the current year, with markups.

\section{B.1 Alternative 1: No Action}

No costs are associated with Alternative 1.

\section{B.2 Alternative 2: Monitoring}

Alternative 2 would involve sampling and analysis for five existing monitoring wells (MW04, MW05, MW06, MW07, MW08) at Ramona in years 1, 2, 3 (if needed), 5, and 10. Results would be reported after each monitoring event. Automated water level measurement would continue in five monitoring wells equipped with data loggers. Data downloads would occur yearly. Two 5-yr reviews would be conducted. Site closeout activities would occur after the second 5-yr review, if appropriate. 
Ten-year costs for Alternative 2 are estimated as follows:

\begin{tabular}{lcc}
\multicolumn{1}{c}{ Item } & & Estimated Cost (\$) \\
\cline { 1 - 1 } $\begin{array}{l}\text { Monitoring and } \\
\text { reporting }\end{array}$ & & 85,000 \\
Five-year reviews (two) & & 47,000 \\
Site closeout & & 10,000 \\
TOTAL & & 142,000 \\
NPV TOTAL & & 116,000
\end{tabular}

\section{B.3 Alternative 3: Environmental Use Controls}

Alternative 3 would involve sampling, analysis, water level measurement, reporting, and site closeout activities. The five existing monitoring wells would be sampled in years 1, 2, 3 (if needed), 5, and 10. Results would be reported after each monitoring event. Two 5-yr reviews would be conducted. Site closeout would occur after the second 5-yr review, if appropriate.

Alternative 3 would involve the establishment of EUCs (tentatively assumed to be Category 2) for the Ramona site. The CCC/USDA would pay any agreement fees and assist the property owner in completing and notarizing an EUC Application to Participate (KDHE 2007d) and in registering the agreement with the Marion County Register of Deeds. Costs associated with the EUC (Category 2) would include a one-time $\$ 10,000$ application fee. Ten-year costs for Alternative 3 are estimated as follows:

\begin{tabular}{lcc}
\multicolumn{1}{c}{ Item } & & $\begin{array}{c}\text { Estimated Cost } \\
(\$)\end{array}$ \\
\cline { 1 - 1 } Monitoring and reporting & & 85,000 \\
EUC application fee & & 10,000 \\
Five-year reviews (two) & & 47,000 \\
Site closeout & & 10,000 \\
TOTAL & & 152,000 \\
NPV TOTAL & & 126,000
\end{tabular}

\section{B.4 Alternative 4: ISCR Treatment}

Alternative 4 would involve the site closeout and 5-yr review activities described for Alternative 2. Alternative 4 would further involve ISCR treatment. The cost estimate assumes a 
single treatment in existing well MW07 in the first year. The cost estimate also assumes the installation of two additional wells downgradient from MW07, specifically for performance monitoring. Subsequent monitoring would involve treatment-specific sampling and analysis for the two newly installed wells and existing well MW04, quarterly in year 1, twice annually in year 2, and annually in years 3-5. In addition, the other four wells in the existing five-well network would be sampled annually in years 1-5. This monitoring would be expected to substantiate a decrease in carbon tetrachloride concentration to a level below $5 \mu \mathrm{g} / \mathrm{L}$. The depth to groundwater is assumed to be $49 \mathrm{ft}$ BGL, and the thickness of the aquifer is assumed to be $6 \mathrm{ft}$. Treatment is assumed to be successful within $5 \mathrm{yr}$.

Costs for Alternative 4 for $5 \mathrm{yr}$ are estimated as follows:

\begin{tabular}{|c|c|}
\hline Item & Estimated Cost (\$) \\
\hline Remedial design & 5,000 \\
\hline ISCR performance monitoring well Installation & 17,000 \\
\hline ISCR treatment and professional labor management & 5,000 \\
\hline Monitoring and reporting & 136,000 \\
\hline Five-year review (one) & 23,000 \\
\hline Site closeout & 10,000 \\
\hline TOTAL & 196,000 \\
\hline NPV TOTAL & 177,000 \\
\hline
\end{tabular}


Argonne

Environmental Science Division

Argonne National Laboratory

9700 South Cass Avenue, BIdg. 203

Argonne, IL 60439-4843

www.anl.gov 